\title{
A SYNOPSIS OF THE SPECIES OF BOECKELLA AND PSEU- DOBOECKELLA WITH A KEY TO THE GENERA OF THE FRESH-WATER CENTROPAGIDAE.
}

\author{
By C. Dwight Marsh, \\ Of the United States Department of Agriculture.
}

The fresh-water genera of Centropagidae are of a great deal of interest because of the rather restricted distribution of many of the species, and a thorough study of these animals from a morphological standpoint is likely to throw much light on their phylogeny and furnish valuable data for the theories of geographical distribution. For this study it is not only helpful but also necessary to have a synopsis giving the species characteristics in a fairly complete but brief form. Giesbrecht and Schmeil's Copepoda Gymnoplea, published in 1898, did this in an admirable manner; many publications have been issued since 1898, however, and new species and genera have been added. The author has had in mind the preparation of synopses of the fresh-water genera of copepods, and the present paper is a contribution to that end. This publication has resulted from a personal need of a synopsis of the genera Boeckella and Pseudoboeckella.

It is perhaps not necessary to go into a discussion of the morphological relations of Boeckella and Pseudoboeckella. This has been done at some length by Ekman, 1905, and the author accepts his conclusions. Pseudoboeckella Mrazek differs from Boeckella DeGuerne and Richard by the fact that the endopodite of the right fifth foot of the male is always 3 segmented with the distal segment armed with setae. It is possible that the differences between Boeckella and Pseudoboeckella should hardly be considered of generic value, but the distinction is a convenient one, and it seems wise to use the two generic names.

KEY TO THE GENERA OF THE CENTROPAGIDAE OF FRESH WATER.

(Endopodites of feet 1-5, 2 segmented .................. Calamoecia Brady.

Endopodites of feet $1-4,1$ segmented .............................. 2

Endopodites of feet 1, 1 segmented; $2-4,2$ segmented.................. 3

1.

Endopodites of feet $1-4,3$ segmented ............................... 4

Endopodites of feet $1-5,3$ segmented ............................... 6

Endopodites of feet 1, 2 segmented; 2-4, 3 segmented, endopodites female

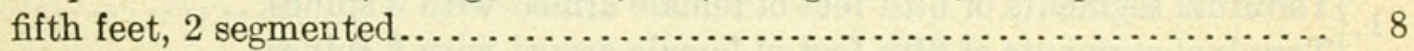

No. 2498.-Proceedings U. S. National museum, Vol. 64, Art. 8. 
Abdomen of male symmetrical, fifth feet of female without endopodites, exop-

2. odites of 3 segments, the distal terminating in a long spine .... Heterocope Sars.

Abdomen of male asymmetrical, fifth feet of female without endopodites, exopodites of 3 segments, the distal not terminating in a spine.... Epischura Forbes. Exopodites of feet 1-4, 3 segmented; in female fifth feet endopodites 2 seg-

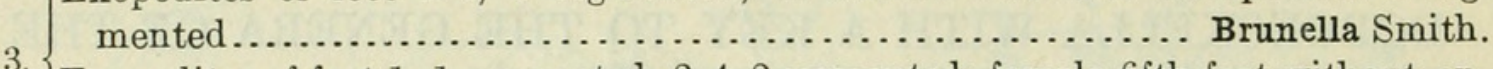

Exopodites of feet 1, 1 segmented; 2-4, 2 segmented; female fifth feet without en-

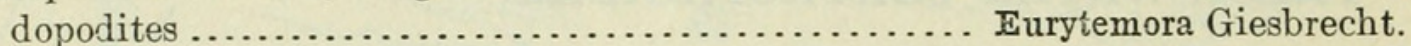

fFirst antennae 20-22 segmented................ Pseudodiaptomus Herrick.

4. $\{$ First antennae 25 segmented ................................. 5

Female fifth feet without endopodites, male fifth feet with terminal hook on right foot only and the hook is turned outward instead of inward.

Poppella Richard.

5. Female fifth feet with endopodites, male fifth feet with terminal hooks on both ex-

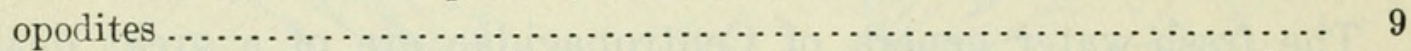

Female fifth feet with endopodites, male fifth feet with terminal hook on right exopodite only, fourth feet with a long curved spine on inner distal angle on first basal segment ................................ Gladioferens Henry. (Exopodites of second antennae, 5 segmented, 2, 3, and 4 being short.

Parabroteas Mrazek.

Limnocalanus Daday, Gigantella Ekman, Parabroteas Ekman.

6. Exopodites of second antennae, 6 segmented, 2-5 being short.

Sinocalanus Burckhardt.

Exopodites of second antennae 7 segmented, 1, 3, 4, 5, and 6 being short..... 7

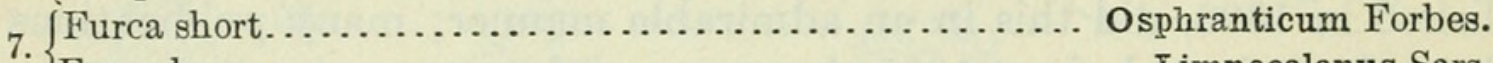

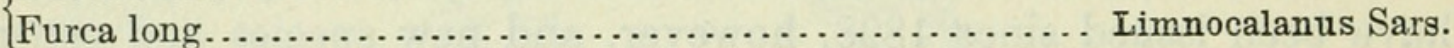

In the male fifth feet both exopodites terminate in an elongated hook; in the female fifth feet the exopodites are distinctly 3 segmented.

Metaboeckella Ekman. Boeckella (dilatata) Sars.

8. In the male fifth feet only the right exopodite terminates in an elongated hook, in the female fifth feet the third segments of the exopodites are either rudimen-

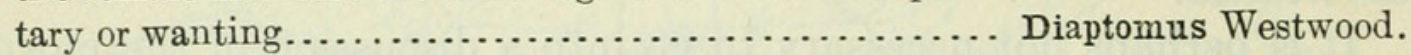

Hemidiaptomus Sars, Paradiaptomus Sars.

(Endopodites of right fifth foot of male rudimentary, 1-3 segmented, without

9. \{ setae............................. Boeckella DeGuerne and Richard.

Endopodite of right fifth foot of male, 3 segmented, with setae.

Pseudoboeckella Mrazek.

\section{Genus BOECKELLA DeGuerne and Richard.}

(Boeckia Thompson, 1883.

Boeckella (part) DeGuerne and Richard, 1889.-Sars, 1894, 1896, 1901, 1903,

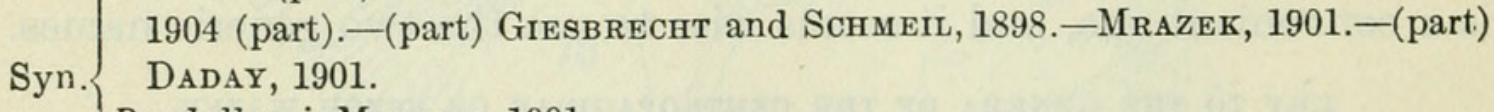

Boeckellopsis MrazEK, 1901.

Pseudoboeckella Daday, 1902, 1905.-EKman, 1905.

Hemiboeckella, Sars, 1911.

KEY TO SPECIES OF BOECKELLA.

(Terminal segments of exopodites of fifth feet of female armed with 2 spines.

1.

Terminal segments of fifth feet of female armed with 3 spines.............. 2

Terminal segments of fifth feet of female armed with 6 spines............. 6

Terminal segments of exopodites of fifth feet of female armed with 7 spines or

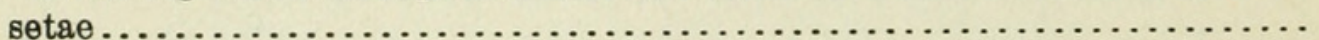


Right endopodite of male fifth feet of 1 segment...................... 3

2. Right endopodite of male fifth feet of 2 segments.................. 4

Right endopodite of male fifth feet of 3 segments..................... 5

First antennae reach to second abdominal segment, right endopodite of male fifth feet very short, digitate...................................

3. First antennae extend to end of furca, right endopodite of male fifth feet equals the first two segments of the exopodite, is pointed and curved inward.

occidentalis Marsh.

The first antennae extend to end of furca, the last thoracic segment of the female is only slightly produced, the left endopodite of the male fifth feet is of one

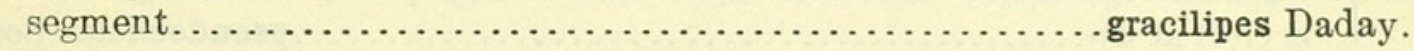

4. The first antennae reach the end of the furcal setae, the last thoracic segment of the female reaches the end of the first abdominal segment, the left endopodite of the male fifth feet is of 2 segments................... poopoensis Marsh.

(Lobes of last thoracic segment in female reach to third abdominal segment.

5 .

Lobes of last thoracic segment of female do not exceed one-half of first abdominal

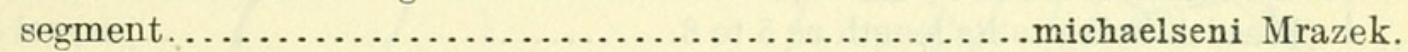

The first antennae reach one-half the length of the furcal setae, the endopodite

6. of the right male fifth foot is 1 segmented................. insignis Smith.

The first antennae reach to the furca, the endopodite of the right male fifth foot

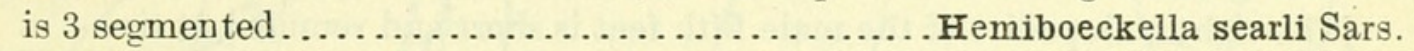

Right endopodite of male fifth feet of 1 segment................... 8

7. Right endopodite of male fifth feet of 2 segments.................. 13

Right endopodite of male fifth feet of 3 segments................... 14

(In male fifth feet the inner margin of the second basal segment of the left foot is serrate, the left endopodite is irregularly curved............. coronaria Henry.

8. In male fifth feet there is a rather prominent serrate lamella on the inner sur-

face of the second basal segment of the left foot.................. 9

In male fifth feet, the second basal segment of the left foot has no serrate margin and bears no serrate lamella ............................. 11

(First antennae of female extend to or beyond the furca, the right endopodite of the male fifth feet has a process or tubercle on the inner surface near the

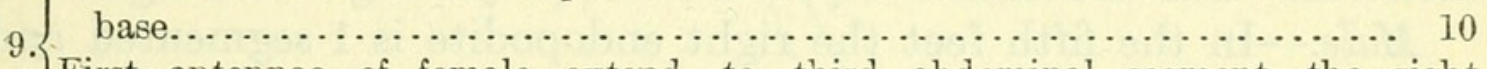

First antennae of female extend to third abdominal segment, the right endopodite of the male fifth feet does not have an inner process or tubercle............................... triarticulata Thompson.

(The lobes of the last thoracic segment in the female extend one half the length of the first abdominal segment.................... oblonga Sars.

The lobes of the last thoracic segment in the female exceed the first abdominal

10. segment, the left endopodite of the male fifth feet is 1 segmented .orientalis Sars.

The lobes of the last thoracic segment in the female exceed the first abdominal segment, the left endopodite of the male fifth feet is 2 segmented.

fluvialis Henry.

The left endopodite of the male fifth feet is short..................... 16

11.

The left endopodite of the male fifth feet equals in length the first segment of

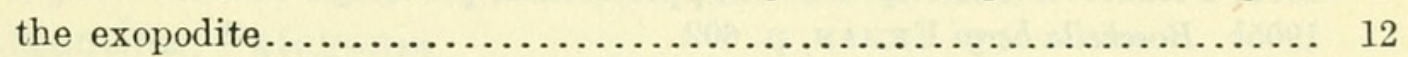

The left endopodite of the male fifth feet is wanting..........asymmetrica Searle. 
In the female the antennae reach the furca, the lobes of the last thoracic segment are short and turned out...................... symmetrica Sars.

12. In the female the antennae extend to end of furca, the lobes of the last thoracic segment turn back and reach one half the length of the first abdominal segment.................................... ${ }^{1}$ Sars.

In the female the antennae extend to the furca, the lobes of the last thoracic segment extend one-half the length of the first abdominal segment.. longiseta Smith.

13. In the female the antennae extend to the abdomen, or to the second abdominal segment, the lobes of the last thoracic segment extend to the second abdominal segment; in the male the hook of the exopodite of the right fifth feet is cleft at tip...................................

14. $\begin{aligned} & \text { Lobes of last thoracic segment of female extend nearly to end of furca. } \\ & \text { nyoraensis Searle. }\end{aligned}$

Lobes of last thoracic segment of female do not exceed second abdominal

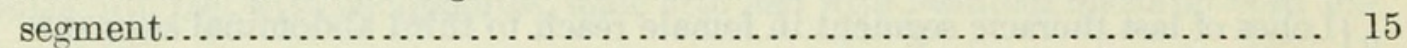

(In the male there is a spine on the inner surface of the first basal segment of the right fifth foot, the endopodite of the left fifth foot is small and broad, its breadth being to its length as 5 to $6 \ldots \ldots \ldots \ldots \ldots \ldots \ldots \ldots \ldots \ldots \ldots \ldots \ldots \ldots \ldots$ saycei Sars.

There is no spine on the first basal segment of the male right fifth foot, the endopodite of the left foot is small and narrow, its breadth being to its

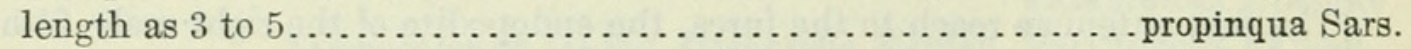

The right endopodite of the male fifth feet is short and rounded at tip.

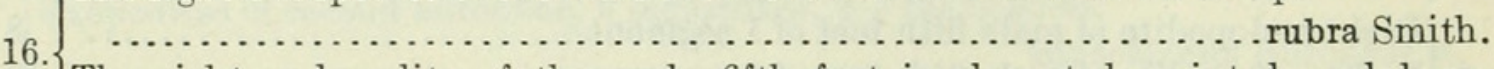

The right endopodite of the male fifth feet is elongated, pointed, and bears near base a short curved spine........................ robusta Sars.

\section{BOECKELLA ASYMMETRICA Searle.}

1914. Boeckella asymmetrica SeArle, p. 192, pl. 10, figs. 1-4.

Female.-The first antennae extend beyond the furcae. The sides of the last thoracic segment consist of two lobes each, which extend back to the second abdominal segment. The two sides are asymmetrical. The abdomen is asymmetrical, projecting to the right.

Male.-In the fifth feet the right endopodite is 1 segmented and extends one-third the length of the second segment of the exopodite; the left endopodite is lacking. Figure 1 shows the fifth feet of the male.

Length.-Male, $0.75 \mathrm{~mm}$.; female, $1.45 \mathrm{~mm}$.

Melbourne, Australia.

BOECKELLA BERGI Richard.

1897. Boeckella bergi RichaRd, pp. 322-325, fig. 2 .

1898. Boeckella bergi Giesbrecht and Schmeil, p. 61.

1901. Boeckella bergi SARS, pp. 6-10, pl. 1, figs. 1-15.

1901. Boeckellopsis bergi MrazeK.

1902. Pseudoboeckella bergi Daday, pp. 220-224, pl. 4, figs. 6-19.

1905b. Boeckella bergi Екмал, p. 602.

Female.-The first antennae extend to the furcae, or to their ends. The sides of the last thoracic segment, consisting of 2 lobes each, extend back to second or third abdominal segment. The first

\footnotetext{
${ }^{1}$ In the opinion of the author, there is no sufficient reason for separating symmetrica and tenera. The male fifth feet are about as near identical as two individuals can be.
} 
abdominal segment is asymmetrical, projecting to the left. The exopodite of the second antenna consists of 7 segments, 1, 3, 4, and 5 being short. The terminal segments of the exopodites of the fifth feet are armed with 3 spines.

Male.-The sides of the last thoracic segment are not lobed and are asymmetrical. In the fifth feet the second basal segments have lamellae on the inner side; the right endopodite is 3 segmented and extends one-half the length of the second segment of the exopodite;
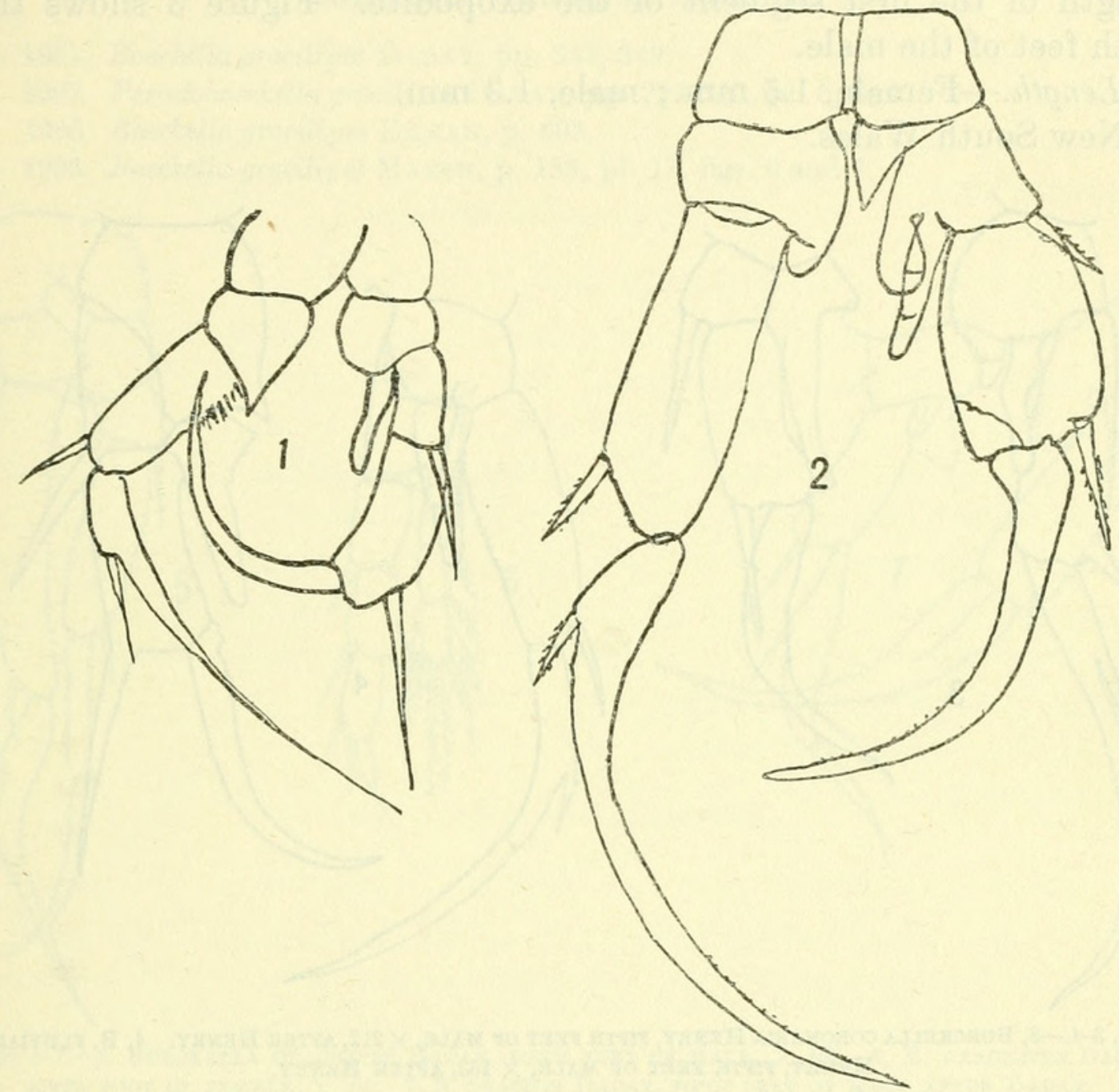

Figs. 1-2.-1, Boeckella asymmetrica Searle, fifth feet of male, after Searle. 2, B. Berg RICHARD, FIFTH FEET OF MALE, AFTER SARS.

the left endopodite is of 1 segment and is minute. Figure 2 shows the fifth feet of the male.

Length.-Male, 1.45-1.8 mm.; female, 1.8-2 mm.

Argentina; Patagonia.

\section{BOECKELla CORONARIA Henry.}

1922. Boeckella coronaria Henry, pp. 557-558, p1. 55, figs. 1-7.

Female.-The first antennae extend to the middle of the furca. The sides of the last cephalothoracic segment flare out somewhat and project back beyond the middle of the first abdominal segment; 
voL. 64 .

the inner lobes are acute. The terminal segments of the exopodites of the fifth feet bear 7 spines.

Male.-The right endopodite of the fifth feet is 1 segmented and extends to the end of the second segment of the exopodite; it has a bluntpointed projection on its inner surface near the base; the distal end is blunt, with a slight indentation. The inner margin of the second basal segment of the left foot is denticulate; the left endopodite is 1 segmented, is of an irregular curved form, and extends two-thirds the length of the first segment of the exopodite. Figure 3 shows the fifth feet of the male.

Length.-Female, $1.5 \mathrm{~mm}$; male, $1.3 \mathrm{~mm}$.

New South Wales.
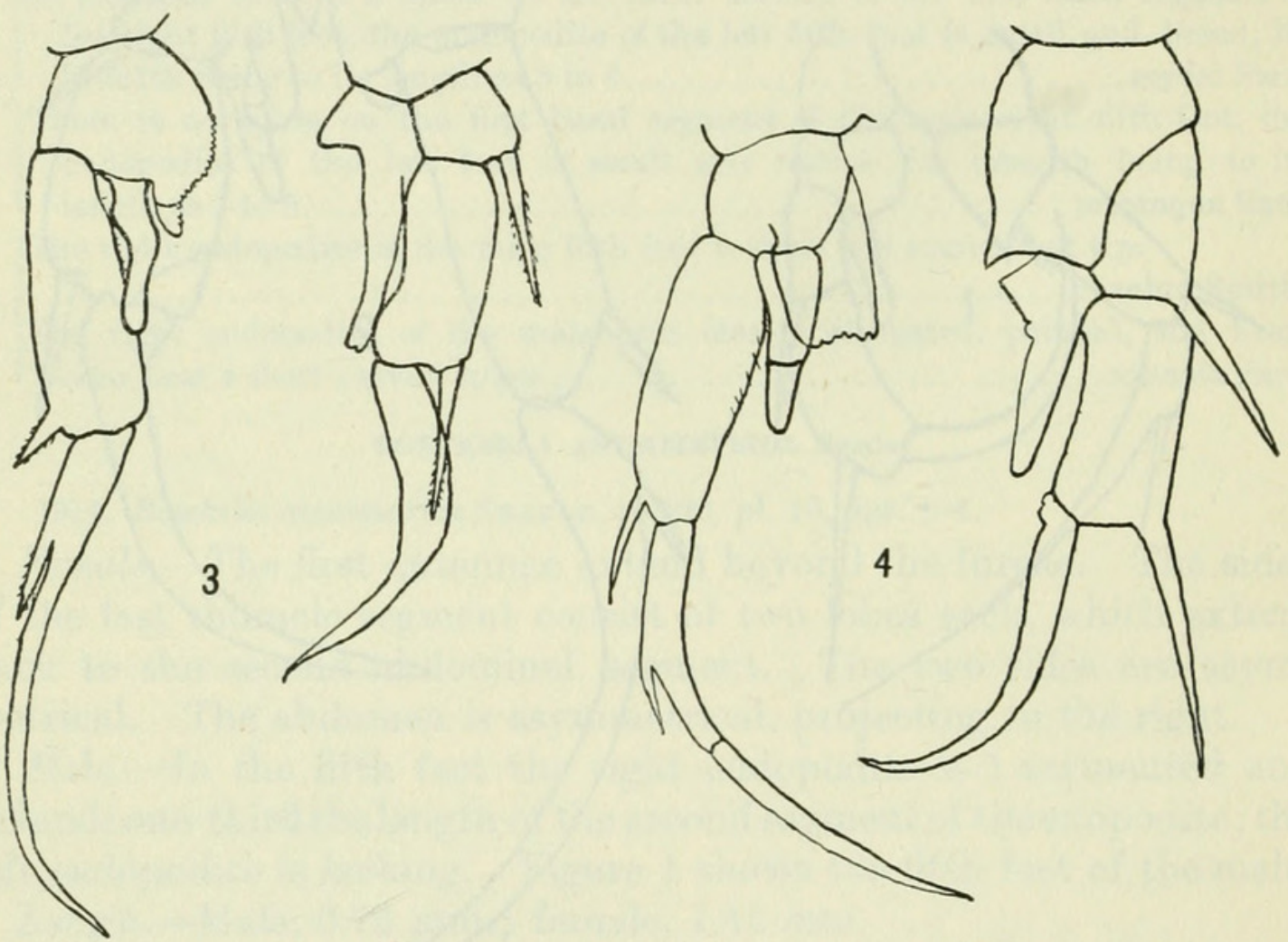

Figs. 3-4.-3, Boeckella coronaria Henry, Fifth Feet of MALe, $\times 212$, After Henry. 4, B. fluvialis HENRY, FIFTH FEET OF MALE, $X 153$, AFTER HENRY.

\section{BOECKELLA FLUVIALIS Henry.}

1922. Boeckella fluvialis Henry, p. 557, pl. 56, figs. 1, 2, and 4-6.

Female.-The first antennae extend nearly to the end of the furcal setae. The sides of thelast cephalothoracic segment extend backward, the projections being slender and acute, and reach the end of the first abdominal segment; the inner lobes are short and rounded with a short pointed projection in the middle. The terminal segments of the exopodites of the fifth feet bear 7 spines.

Male.-In the male fifth feet the right endopodite is 1 segmented and reaches the end of the second segment of the exopodite; it has a blunt-pointed projection on its inner surface near the base; the distal 
end is round and tapering. On the second basal segment of the left foot is a rectangular lamella which is serrate on its distal margin. The left endopodite is 2 segmented and about two-thirds the length of the first segment of the exopodite; the inner margin of the first segment of the exopodite is sparsely ciliate. Figure 4 shows the fifth foot of the male.

Length.-Female, $1.8 \mathrm{~mm}$; male, $1.7 \mathrm{~mm}$.

New South Wales.

\section{BOECKELLA GRACILIPES Daday.}

1901. Boeckella gracilipes DADAY, pp. $348,349$.

1902. Pseudoboeckella gracilipes DADAY, pp. 224-227, pl. 5, figs. 1-7.

1905. Boeckella gracilipes Ekman, p. 603.

1906. Boeckella gracilipes Marsh, p. 183, pl. 17, figs. 6 and 7 .
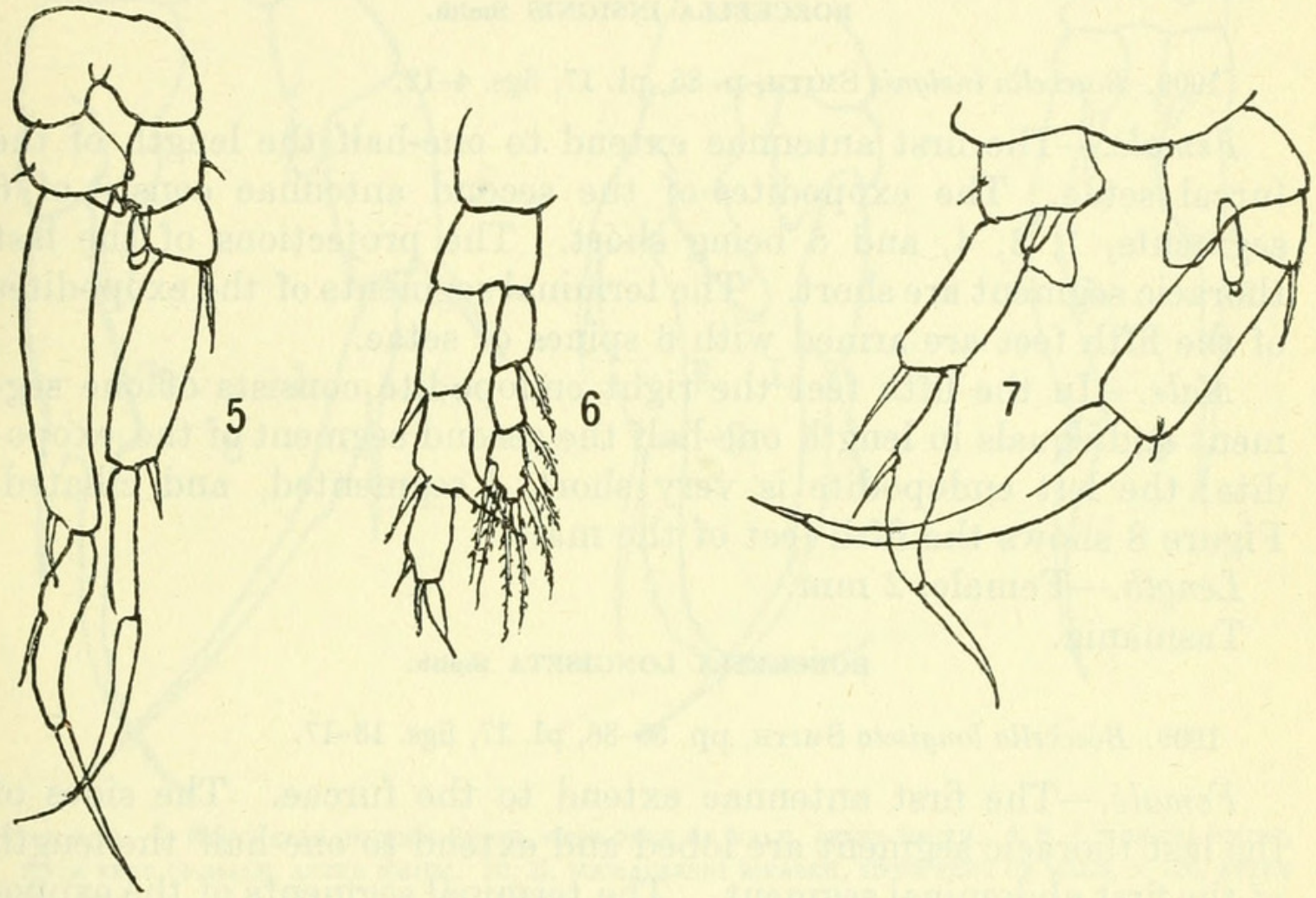

Figs. 5-7.-5, Boeckella gracilipes Daday, fifth feet of male, $\times 165$. 6, B. gracilipes Daday FIFTH FOOT OF FEMALE, $\times 165$. 7, B. GRACILIS DADAY, FIFTH FEET OF MALE, AFTER DADAY.

Female.-The first antennae extend to the end of the furca. The last thoracic segment projects only slightly, the sides not distinctly divided. The terminal segments of the exopodites of the fifth feet are armed with 3 spines.

Male.--In the fifth feet the right endopodite consists of 2 segments and equals in length the first segment of the exopodite. The left endopodite is of one segment and is minute. Figure 5 shows the fifth feet of the male, and Figure 6 the fifth feet of the female.

Length according to Daday.-Male, $0.8 \mathrm{~mm}$.; female, 0.8 to $1.1 \mathrm{~mm}$.

Length according to Marsh.-Male, $1.28 \mathrm{~mm}$.; female, $1.485 \mathrm{~mm}$.

Argentina; Lake Titicaca. 
BOECKELLA GRACILIS Daday.

1902. Pseudoboeckella gracilis DADAY, pp. 227-231, pl. 9, figs. 1 and 9-17.

1905b. Boeckella gracilis Ekman,p. 602.

Female.-The first antennae extend to the second abdominal segment. The sides of the last thoracic segment are not lobed and project somewhat. The terminal segments of the exopodites of the fifth feet are armed with 3 spines.

Male.-Both endopodites of the fifth feet are 1 segmented and small; the second basal segments of both feet bear a cuticular projection on the inner distal angle. Figure 7 shows the fifth feet of the male.

Length.-Male, 1.4 to $1.6 \mathrm{~mm}$; female, 1.7 to $2.2 \mathrm{~mm}$. Argentina.

\section{BOECKELLA INSIGNIS Smith.}

1909. Boeckella insignis Sмiтн, p. 85, pl. 17, figs. 4-12.

Female.-The first antennae extend to one-half the length of the furcal setae. The exopodites of the second antennae consist of 6 segments, 1, 3, 4, and 5 being short. The projections of the last thoracic segment are short. The terminal segments of the exopodites of the fifth feet are armed with 6 spines or setae.

Male.-In the fifth feet the right endopodite consists of one segment and equals in length one-half the second segment of the exopodite; the left endopodite is very short, 1 segmented, and ciliated. Figure 8 shows the fifth feet of the male.

Length.-Female, $2 \mathrm{~mm}$.

Tasmania.

BOECKELLA LONGISETA Smith.

1909. Boeckella longiseta Sмiтн, pp. 85-86, pl. 17, figs. 13-17.

Female.-The first antennae extend to the furcae. The sides of the last thoracic segment are lobed and extend to one-half the length of the first abdominal segment. The terminal segments of the exopodites of the fifth feet are armed with 7 spines or setae.

Male.- In the fifth feet the right endopodite is 2 segmented and extends to one-half the length of the second segment of the exopodite. The left endopodite is rudimentary or wanting; in figure not separated. Figure 9 shows the fifth feet of the male.

Length.-Female, $1.5 \mathrm{~mm}$.

Tasmania.

\section{BOECKELLA MICHAELSENI Mrazek.}

1901. Boeckellina michaelseni Mrazek, pp. 11-12, figs. 10, 33, 36, 47, 48.

1901. Boeckella pygmaea DADAY, pp. 349-350.

1902. Pseudoboeckella pygmaea DADAY, pp. 231-233, pl. 5, figs. 8-12.

1905. Pseudoboeckella anderssonorum ЕкмаN, pp. 10-14, figs. 3-5.

1905b. Boeckella michaelseni EкмаN, p. 603.

1914. Boeckella michuelseni Scotr, pp. 1 and 2, pl. 1, figs. 4-6. 
Female.-The first antennae extend to or beyond the furca. The sides of the last thoracic segment are not lobed and do not reach beyond one-half first abdominal segment. The terminal segments of the exopodites of the fifth feet are armed with 3 spines.

Male.-In the fifth feet the right endopodite is 3 segmented (2 segmented in pygmaea Daday and michaelseni Scott) and nearly or quite equals the first segment of the exopodite; the left endopodite is 1 segmented and rudimentary; the first segment of the left exopodite is convex and spinose on the inner side. Figure 10 shows the fifth feet of the male.
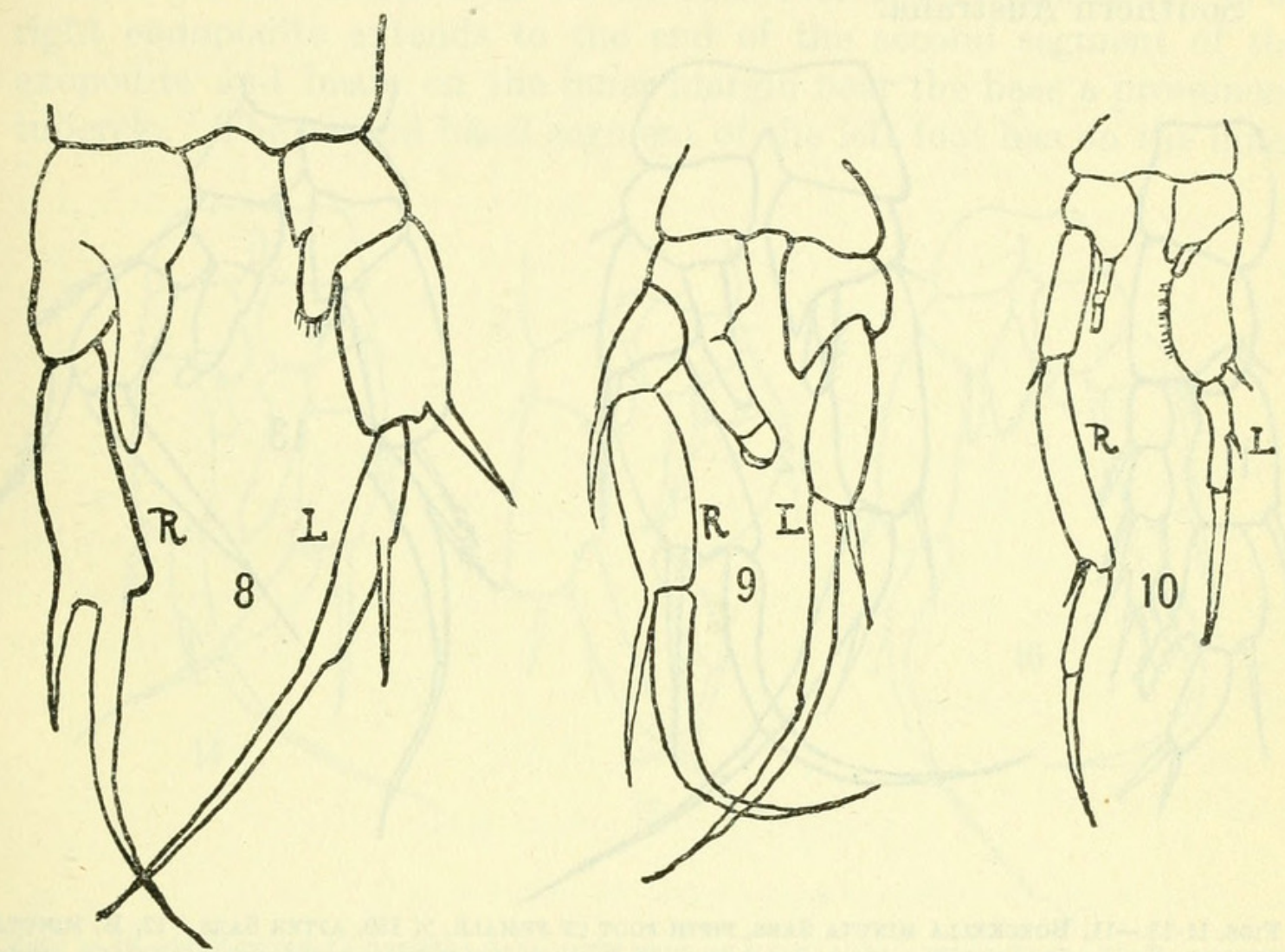

Figs. 8-10.-8, Boeckella insignis SMith, fifth Feet of Male :After SMith. 9, B. Longiseta SMith,

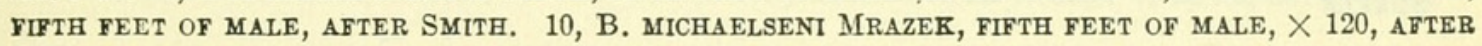
MRAZEK.

Length.-Male, $1 \mathrm{~mm}$; female, $1.15 \mathrm{~mm}$.

Tierra del Fuego; Argentina; Falkland Islands.

BOECKELlA MINUTA Sars.

1896. Boeckella minuta SARs, pp. 71-74, pl. 8, figs. 5-7.

1898. Boeckella minuta Giesbrecht and Schmeil, p. 62.

1908. Boeckella minuta SARs, pp. 10-11, pl. 2, figs. 1-4.

1919. Boeckella minuta Henry, p. 31.

1922. Boeckella minuta Henry, p. 558.

Female.-The first antennae extend to the furca. The sides of the last cephalothoracic segment are produced backward nearly the length of the first abdominal segment and have small inner lobes. 
The abdomen is asymmetrical, the first segment projecting to the left. In the fifth feet the terminal segments of the exopodites are armed with 2 spines.

Male.-In the fifth feet the right endopodite is 1 segmented and does not reach the middle of the second segment of the exopodite; the second basal segment of the left foot is produced on the inner angle; the left endopodite is 1 segmented and less than one-half the length of the first segment of the exopodite. Figure 11 shows the fifth foot of the female, and Figure 12 the fifth feet of the male.

Length.-Male, $1.28 \mathrm{~mm}$.; female, $1.3 \mathrm{~mm}$.

Southern Australia.
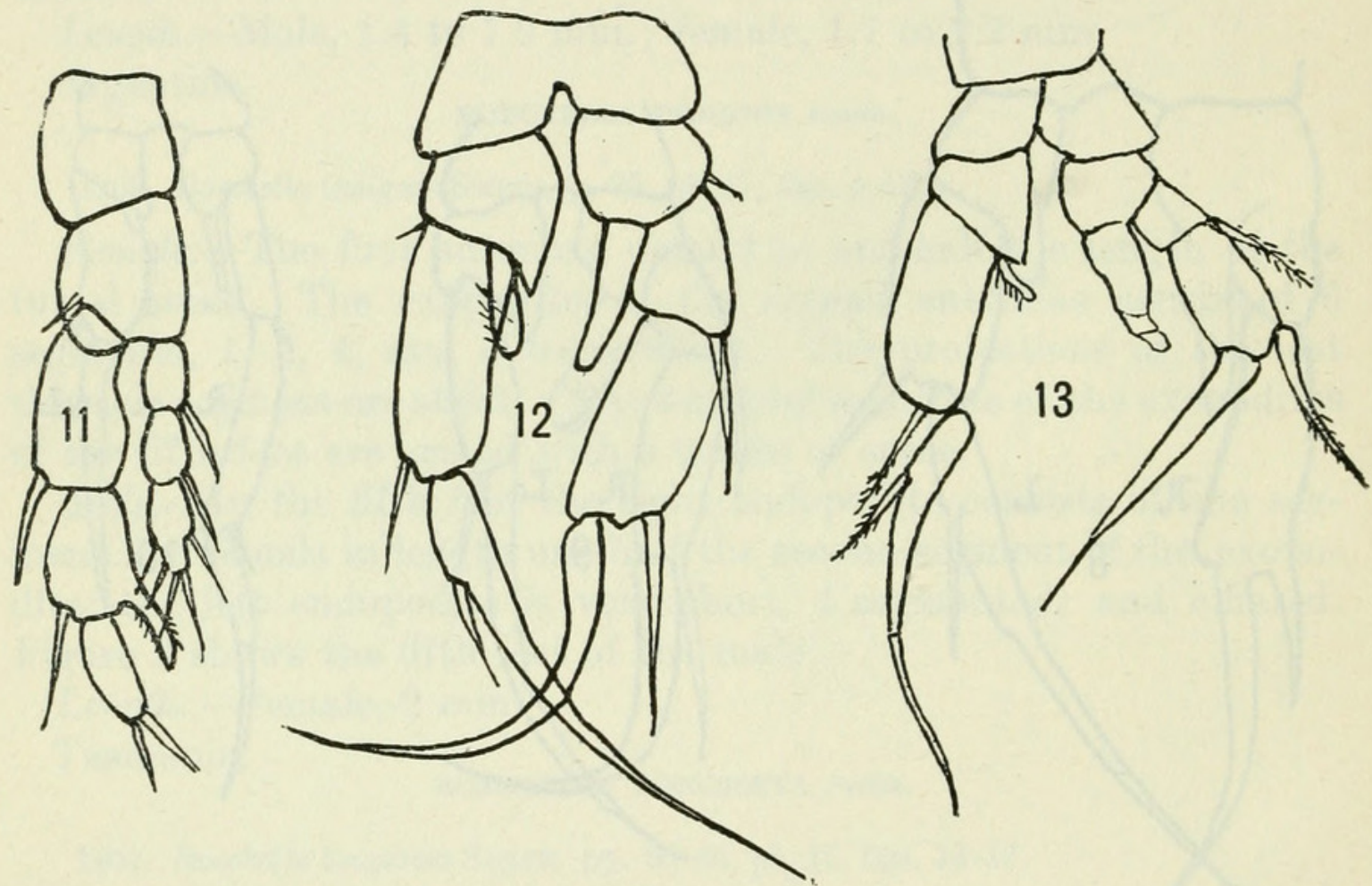

Figs. 11-13.-11, Boeckella minuta Sars, fifth foot of female, $\times 150$, after Sars. 12, B. Minuta SARS, FIFTH FEET OF MALE, $\times 150$, AFTER SARS. 13, B. NYORAENSIS SEARLE, FIFTH FEET OF MALE, AFTER SEARLE

BOECKELLA NYORAENSIS Searle.

1912. Boeckella nyoraensis Searle, 197, pl. 4, figs. 1-4.

Female.-The first antennae extend beyond the furca. The sides of the last cephalothoracic segment project backward nearly to the end of the furca; the projections have inner lobes, the left triangular and acute, the right with parallel sides and rounded tip. The first abdominal segment is asymmetrical. In the fifth feet, the terminal segments of the exopodites bear 7 spines.

Male.-In the fifth feet the right endopodite is 3 segmented and nearly equals in length the first two segments of the exopodite. The left endopodite is minute, slender and 1 segmented. Figure 13 shows the fifth feet of the male.

Length. $-2.6 \mathrm{~mm}$.

Nyora, Victoria. 
BOECKELLA OBLONGA Sars.

1908. Boeckella oblonga SARs, pp. 6 and 7, pl. 1, figs. 5-8.

1922. Boeckella oblonga Henry, pp. 556-557.

Female.-The first antennae extend to the furca. The sides of the last cephalothoracic segment have prominent and acute inner lobes and project back about two-thirds the length of the first abdominal segment. The abdomen is asymmetrical, the right side being the more prominent. The terminal segments of the exopodites of the fifth feet are armed with 7 spines.

Male.-Both endopodites of the fifth feet are 1 segmented. The right endopodite extends to the end of the second segment of the exopodite and bears on the inner margin near the base a prominent tubercle. The second basal segment of the left foot has on the inner
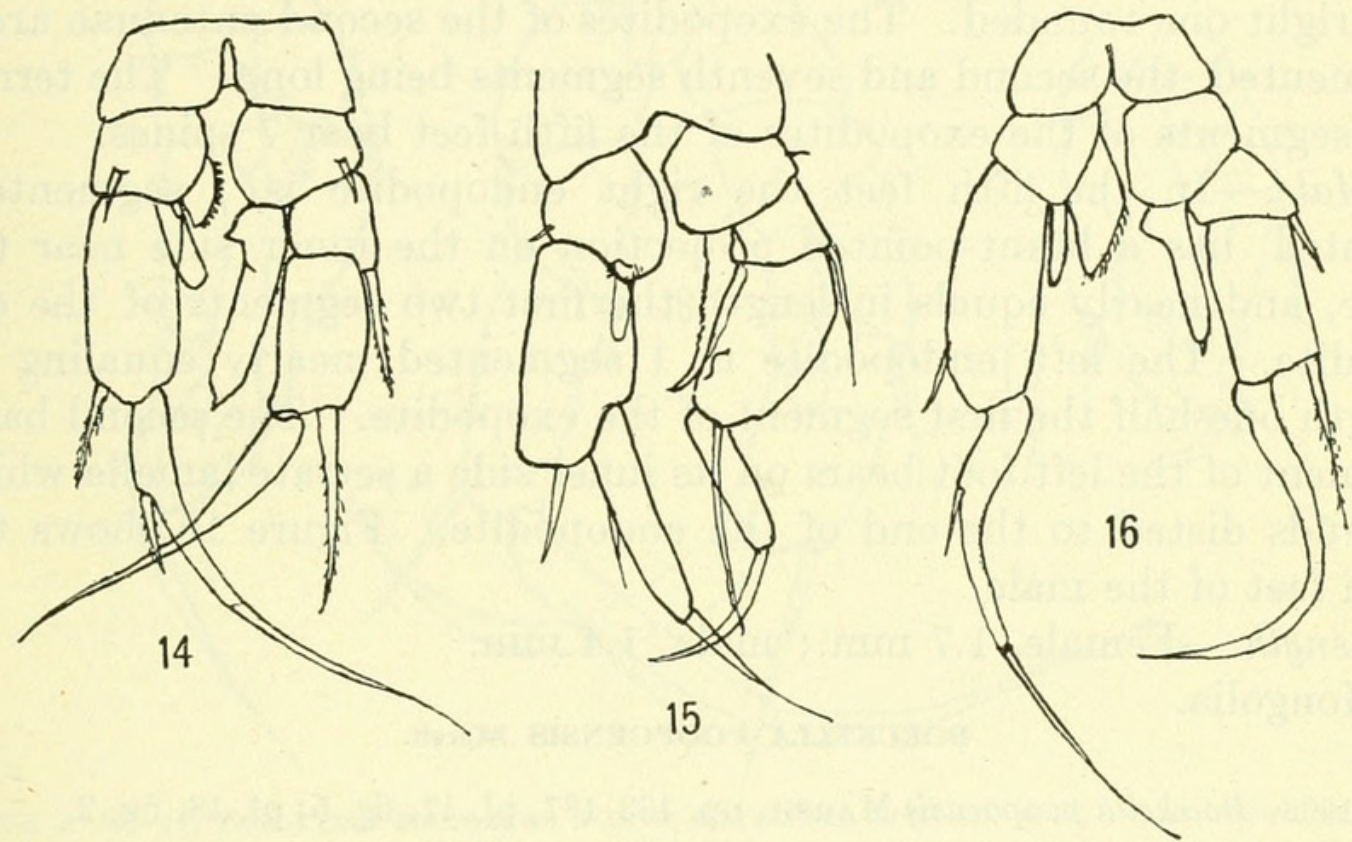

Figs. 14-16.-14, Boeckella oblonga Sars, fifth feet of Male, $\times 114$, after Sars. 15, B. occiden-

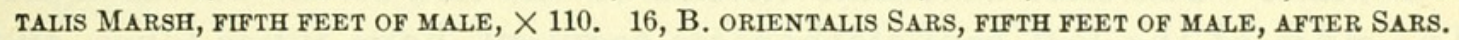

surface a serrate lamella. The left endopodite is one-half the length of the first segment of the exopodite. Figure 14 shows the fifth feet of the male.

Length.-Female, $2 \mathrm{~mm}$.

Southern Australia.

\section{BOECKELLA OCCIDENTALIS Marsh.}

1906. Boeckella occidentalis Marsh, pp. 179-183, pl. 18, figs. 1, 3-6.

Female.-The first antennae extend to the end of the furca. The last segment of the cephalothorax projects backward and has inner lobes. The abdomen is symmetrical. The terminal segments of the exopodites of the fifth feet bear 3 spines. The exopodites of the second antennae consist of 7 segments, $1,3,4,5$, and 6 being short.

Male.-In the fifth feet the right endopodite is 1 segmented, pointed, and curved inward, and reaches the end of the second seg- 
ment of the exopodite. The left endopodite is 1 segmented and less than one-half the first segment of the exopodite. The second segment of the right exopodite bears on the inner surface near the distal end a rather prominent tubercle. Figure 15 shows the fifth feet of the male.

Length.-Female, $1.505 \mathrm{~mm}$.; male, $1.43 \mathrm{~mm}$.

Lake Titicaca and Lake Poopo.

\section{BOECKELLA ORIENTALIS Sars.}

1903. Boeckella orientalis SARs, pp. 196-197, pl. 9, figs. 1-15.

1905b. Boeckella orientalis Екмал, p. 602.

Female.-The first antennae reach the furca. The last cephalothoracic segment is produced backward on the sides beyond the first abdominal segment; it has inner lobes, the left one being acute and the right one rounded. The exopodites of the second antennae are 7 segmented, the second and seventh segments being long. The terminal segments of the exopodites of the fifth feet bear 7 spines.

Male.-In the fifth feet the right endopodite is 1 segmented, pointed, has a blunt-pointed projection on the inner side near the base, and nearly equals in length the first two segments of the exopodite. The left endopodite is 1 segmented, nearly equaling in length one-half the first segment of the exopodite. The second basal segment of the left foot bears on its inner side a serrate lamella which extends distad to the end of the endopodite. Figure 16 shows the fifth feet of the male.

Length.-Female, $1.7 \mathrm{~mm}$; male, $1.4 \mathrm{~mm}$.

Mongolia.

BOECKELLA POOPOENSIS Marsh.

1906. Boeckella poopoensis MARSH, pp. 183-187, pl. 17, fig. 5; pl. 18, fig. 2.

Female.-The first antennae extend to the end of the furcal setae. The sides of the last cephalothoracic segment have inner lobes and project backward the length of the first abdominal segment. The exopodites of the second antennae consist of 5 segments. The terminal segments of the exopodites of the fifth feet are armed with 3 spines. The third segment of the endopodites of the fifth feet bear 5 setae.

Mule.-In the fifth feet each of the second basal segments bears a blunt spine near the inner distal angle. The endopodites are 2 segmented; the right reaches one-half the length of the second segment of the exopodite and the left one-half the length of the first segment of the exopodite. Figure 17 shows the fifth feet of the male.

Length.-Male, $1.4 \mathrm{~mm}$; female, $1.53 \mathrm{~mm}$.

Lake Poopo. 
BOECKella PropinQUA Sars.

1904. Boeckella propinqua SARs, pp. 636-638, pl. 35, figs. $10 a-h$.

1905b. Boeckella propinqua Екмал, p. 602.

1906. Boeckella propinqua BrADY, p. 696.

Female.-The first antennae extend beyond the furca. The exopodites of the second antennae are composed of 7 segments. The last cephalothoracic segment projects backward on the sides the length of the first abdominal segment; the projections have inner lobes which are rounded. The first abdominal segment is asymmetrical. In the fifth feet the terminal segments of the exopodites are armed with 7 spines.

Male.-In the fifth feet the right endopodite consists of 3 segments and extends to about one-third the length of the second

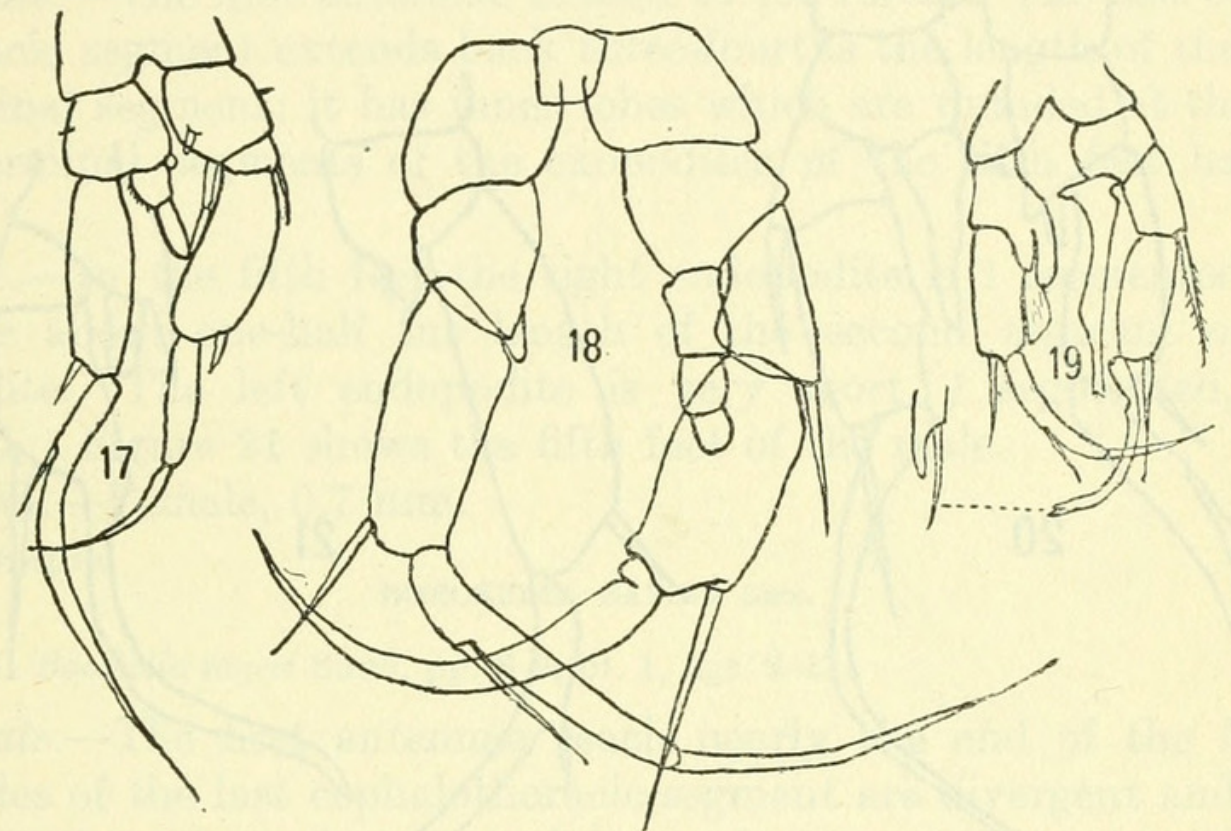

Figs. 17-19.-17, Boeckella poopoensis Marsh, fifth feet of Male, $\times$ 44. 18, B. Propinqua Sars, Fifth feet of Male, $X 56$, after Sars. 19, B. pSeudocheles Searle, fifth feet of male, after SEARLE.

segment of the exopodite. The left endopodite is 1 segmented and very short. Figure 18 shows the fifth feet of the male

Length.-Female, $1.4 \mathrm{~mm}$.

New Zealand.

BOECKELLA PSEUDOCHELES Searle.

1912. Boeckella pseudochelae SeArle, p. 198, pl. 5, figs. 1-9.

1912. Boeckella pseudocheles SARs, pp. 12-13, pl. 8, figs. 10-15.

1922. Boeckella pseudocheles Henry, p. 559.

Female.-The first antennae are slightly longer than the cephalothorax. The sides of the last cephalothoracic segment flare outward and project backward to the second abdominal segment: they have inner lobes which are acute. The terminal segments of the exopodites of the fifth feet have 7 spines. 
Male.-In the right fifth foot the terminal hook of the exopodite is divided at the tip, making an imperfect chela. The endopodite is 2 segmented, angular; the proximal segment has a blunt internal projection near the base and the distal segment is notched at the end; the endopodite exceeds in length the first two segments of the exopodite.

The second segment of the left exopodite, as shown by Sars, has 2 spines instead of 1 as is customary in this genus. The second basal segment of the left fifth foot has a smooth lamella projecting from its inner surface. The endopodite is 1 segmented, short, and lamelliform. Figure 19 shows the fifth feet according to Searle.
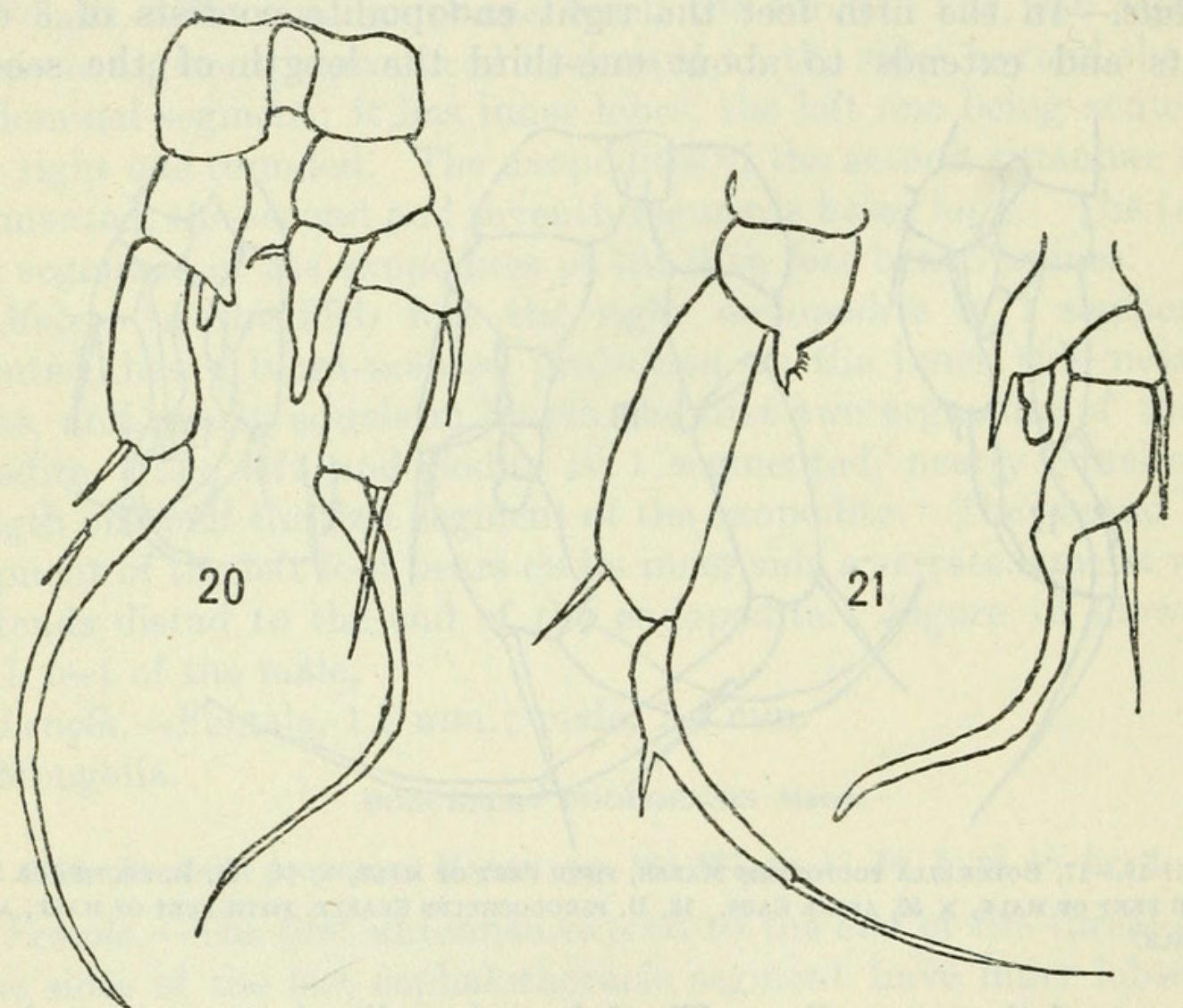

Figs. 20-21.-20, Boeckella robusta Sars, fifth feet of male, after Sars. 21, B. rubra Smith FIFTH FEET OF MALE, AFTER SMith.

Length.-Male, according to Searle, $2.5 \mathrm{~mm}$; female, according to Sars, $2.35 \mathrm{~mm}$.

Southern Australia.

BOECKELLA ROBUSTA Sars.

1896. Boeckella robusta SARs, pp. 66-71, pl. 8, figs. 1-4.

1898. Boeckella robusta Giesbrecht and SchmeIL, p. 61.

1905b. Boeckella robusta EKMAN, p. 602.

1909. Boeckella robusta SмiтH, p. 87.

1922. Boeckella robusta Henry, p. 558.

Female.-The first antennae extend to the abdomen. The last cephalothoracic segment is produced backward somewhat beyond the first abdominal segment; the projections have small inner lobes 
which are pointed. The first abdominal segment is slightly asymmetrical. In the fifth feet the terminal segments of the exopodites are armed with 7 spines.

Male.--In the fifth feet the right endopodite is 1 segmented, pointed, and extends nearly to the end of the second segment of the exopodite; it bears on the inner margin near the base a short curved spine. The left endopodite is 1 segmented and very short. Figure 20 shows the fifth feet of the male.

Length.-Female, $3.2 \mathrm{~mm}$.

Southern Australia.

BOECKELLA RUBRA Smith.

1909. Boeckella rubra Sмiтн, p. 86 , pl. 18, figs. 1-5.

Female.-The first antennae extend to the furca. The last cephalothoracic segment extends back three-fourths the length of the first abdominal segment; it has inner lobes which are rounded at the tip. The terminal segments of the exopodites of the fifth feet have 7 spines.

Male.-In the fifth feet the right endopodite is 1 segmented and extends about one-half the length of the second segment of , the exopodite. The left endopodite is very short, 1 segmented, and pointed. Figure 21 shows the fifth feet of the male.

Length.-Female, $0.7 \mathrm{~mm}$.

Tasmania.

BOECKELLA SAYCEI Sars.

1908. Boeckella saycei SARs, pp. 8-9, pl. 1, figs. 9-13.

Female.-The first antennae reach nearly the end of the furca. The sides of the last cephalothoracic segment are divergent and produced backward to the third abdominal segment; they have inner lobes which are small with rounded tips. In the fifth feet the terminal segments of the exopodites are armed with 7 spines.

Male.--In the right fifth foot the second basal segment has a short broad spine on its inner margin; the endopodite is 3 segmented, exceeding in length the first segment of the exopodite. The left endopodite is short and lamelliform. Figure 22 shows the fifth feet of the male.

Length.-Female, $1.5 \mathrm{~mm}$.

Southern Australia.

\section{BOECKELLA SEARLI Sars.}

1912. Hemiboeckella searli SARs, pp. 13-18, pl. 9, figs. 1-14

1922. Hemiboeckella searli Henry, pp. 560-561.

Female.-The first antennae extend to the abdomen. The sides of the last cephalothoracic segment have no inner lobes and project back very slightly. The first abdominal segment is slightly asymmetrical. The exopodites of the second antennae consist of $7 \mathrm{seg}-$ 
ments, $1,2,4,5$, and 6 being short. The terminal segments of the exopodites of the fifth feet are armed with 6 spines.

Male.-In the fifth feet the right endopodite is 3 segmented, the second segment having on its inner distal angle an acute cuticular projection extending twice the length of the third segment. The left endopodite is 2 segmented, the second segment bearing on its inner side a seta-like projection. The second basal segment of the left foot has on its inner distal angle a broad cuticular process reaching to the middle of the second segment of the exopodite; the second segment of the exopodite has a small external spine and a rather
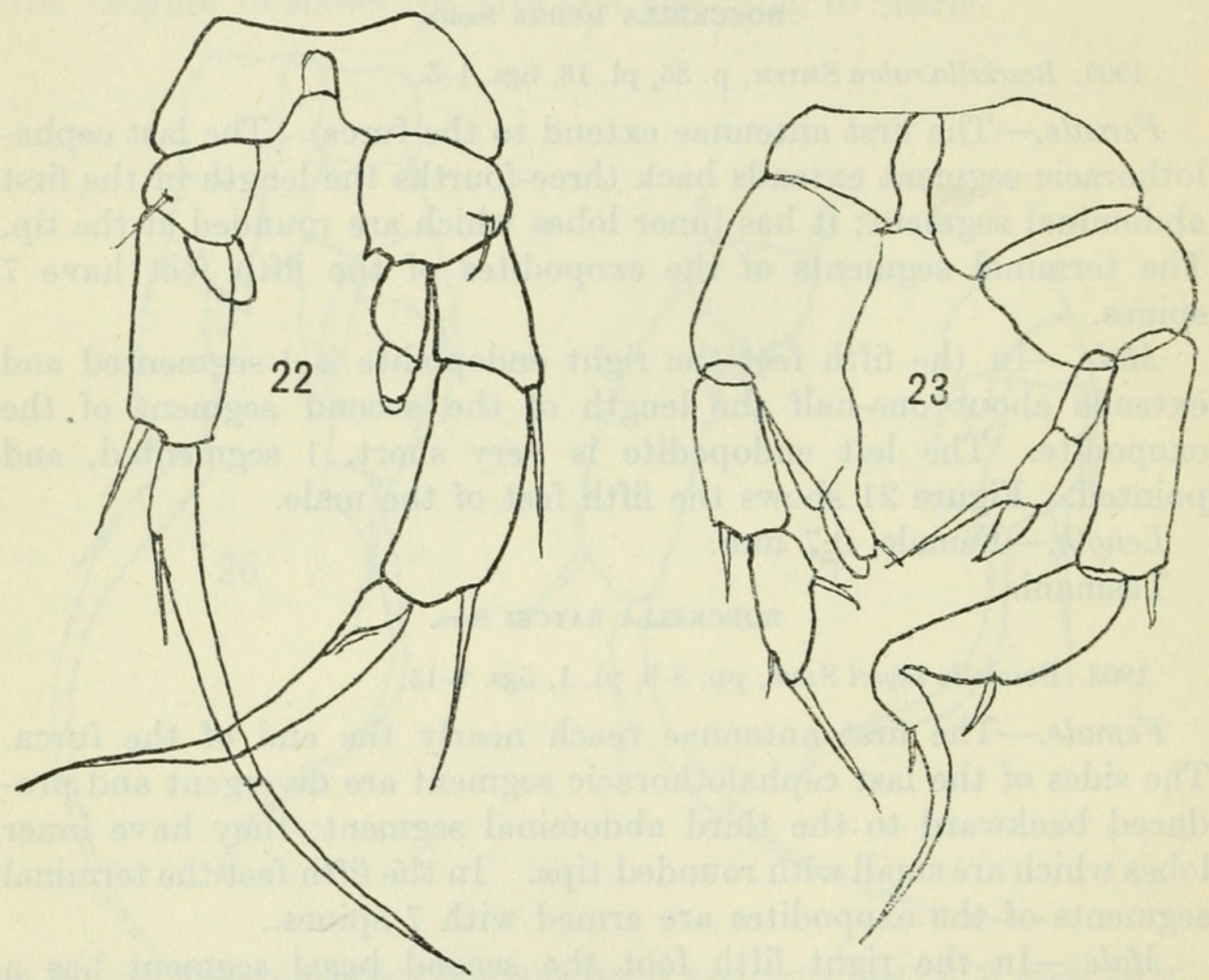

Figs. 22-23.-22, Boeck ella SAycei Sars, fifth feet of Male $\times 170$, after SARs. 23, B. SEarli Sars, FIFTH FEET OF MALE, AFTER SARS.

strong curved spine about midway of its inner border. Figure 23 shows the fifth feet of the male.

Length.-Male, $1 \mathrm{~mm}$.; female, $1.6 \mathrm{~mm}$.

Southern Australia.

Sars makes the new genus Hemiboeckella for this"species, but I see no good reason for separating it from Boeckella.

\section{BOECKELLA SYMMETRICA Sars.}

1908. Boeckella symmetrica SARs, pp. 9-10, pl. 1, figs. 14-17.

Female.-The first antennae extend to the furca. The lateral extensions of the last cephalothoracic segment are very short and pro- 
ject from the body at very nearly right angles; they have inner lobes which are acute. The terminal segments of the exopodites of the fifth feet have 7 spines.

Male.-In the fifth feet the right endopodite is 1 segmented, conical in form, and extends three-fourths the length of the second segment of the exopodite. The second basal segment of the left foot has on the inner distal angle a small, smooth lamella. The left endopodite is 1 segmented, rounded at the end, and nearly equals in length the first segment of the exopodite. Figure 24 shows the fifth feet of the male.

Length.-Female, $1.6 \mathrm{~mm}$.

Southern Australia.
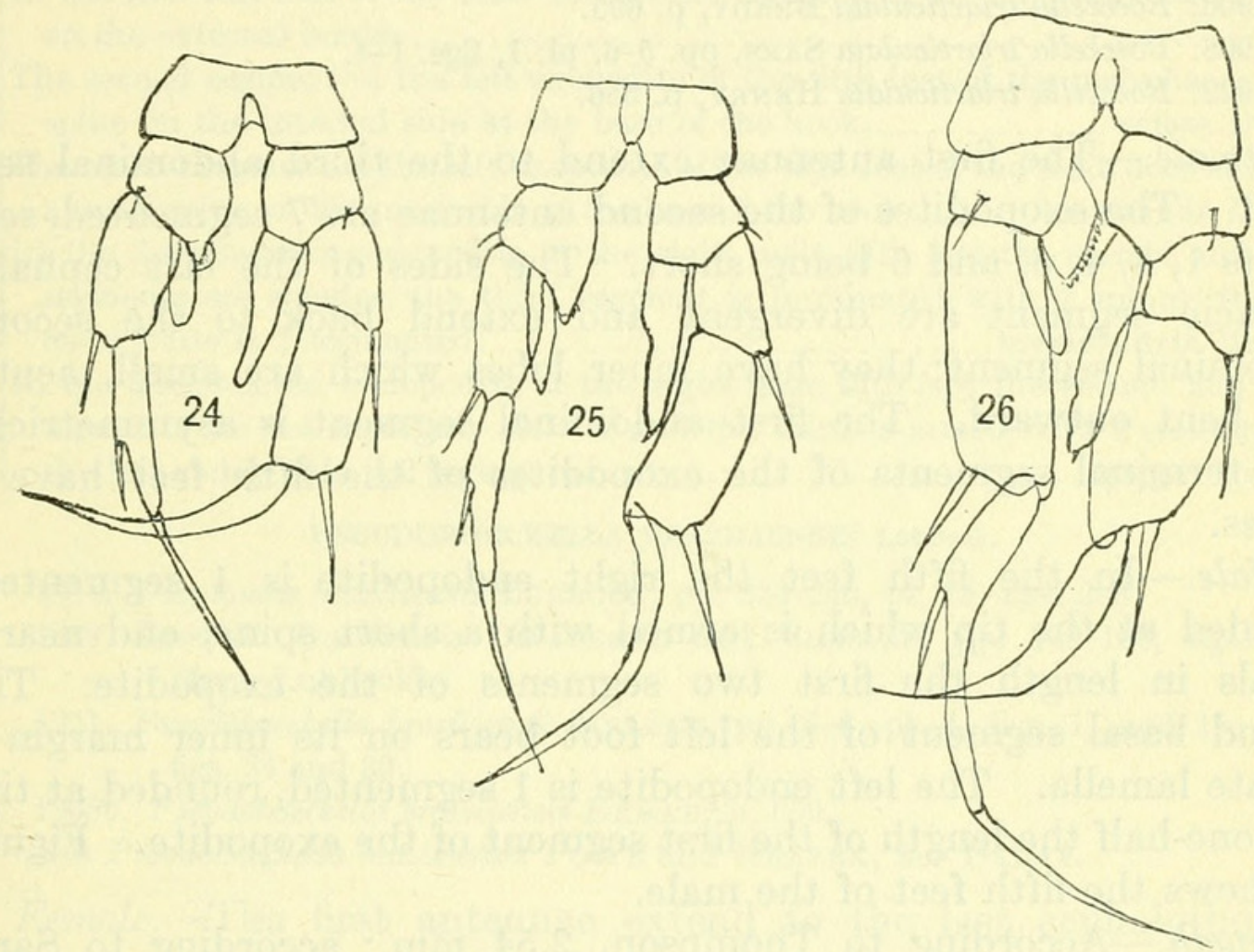

Figs. 24-26.-24, Boeckella symmetrica Sars, fifth feet of Male, $\times$ 114, after Sars. 25, B. tenera

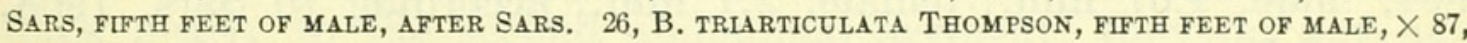
AFTER SARS.

\section{BOECKELLA TENERA Sars.}

1912. Boeckella tenera SARs, pp. 10-12, pl. 8, figs. 6-9.

Female.-The first antennae extend to the enc of the furca. The sides of the last cephalothoracic segment are produced backward nearly one-half the length of the first abdominal segment; the left side is much larger than the right; they have inner lobes which are small and spiniform. The terminal segments of the exopodites of the fifth feet have 7 spines.

Male.-In the fifth feet the right endopodite is 1 segmented, pointed, and extends about one-half the length of the second segment of the exopodite. The second basal segment of the left foot has on 
its inner distal angle a denticulate lamellar projection. The left endopodite is 1 segmented and equal in length to the first segment of the exopodite. Figure 25 shows the fifth feet of the male.

Length.-Female, $1.8 \mathrm{~mm}$.

Southern Australia.

\section{BOECKELLA TRIARTICULATA Thompson.}

1883. Boeckia triarticulata Thомpson, p. 95, pl. 6, figs. 1-9.

1889. Boeckella triarticulata DeGuerne and Richard, p. 103, figs. 57-58.

1894. Boeckella triarticulata SARs, p. 49, pl. 7, figs. 1-8; pl. 8, figs. 1-9.

1896. Boeckella triarticulata SARs, p. 66.

1898. Boeckella triarticulata Giesbrecht and Schmeil, p. 61.

1905b. Boeckella triarticulata EкмаN, p. 602.

1906. Boeckella triarticulata BRAdy, p. 695.

1908. Boeckella triarticulata SARs, pp. 5-6, pl. 1, figs. 1-4.

1922. Boeckella triarticulata Henry, p. 556.

Female.-The first antennae extend to the third abdominal segment. The exopodites of the second antennae are 7 segmented, segments $1,3,4,5$, and 6 being short. The sides of the last cephalothoracic segment are divergent and extend back to the second abdominal segment; they have inner lobes which are small, acute, and bent outward. The first abdominal segment is asymmetrical. The terminal segments of the exopodites of the fifth feet have 7 spines.

Male.-In the fifth feet the right endopodite is 1 segmented, rounded at the tip which is armed with a short spine, and nearly equals in length the first two segments of the exopodite. The second basal segment of the left foot bears on its inner margin a serrate lamella. The left endopodite is 1 segmented, rounded at tip, and one-half the length of the first segment of the exopodite. Figure 26 shows the fifth feet of the male.

Length.-According to Thompson, $2.54 \mathrm{~mm}$; according to Sars, 1894, male, $1.67 \mathrm{~mm}$.; female, $2.1 \mathrm{~mm}$.; according to Sars, 1908, female, $2.5 \mathrm{~mm}$.

Australia; New Zealand.

\section{Genus PSEUDOBOECKELLA Mrazek.}

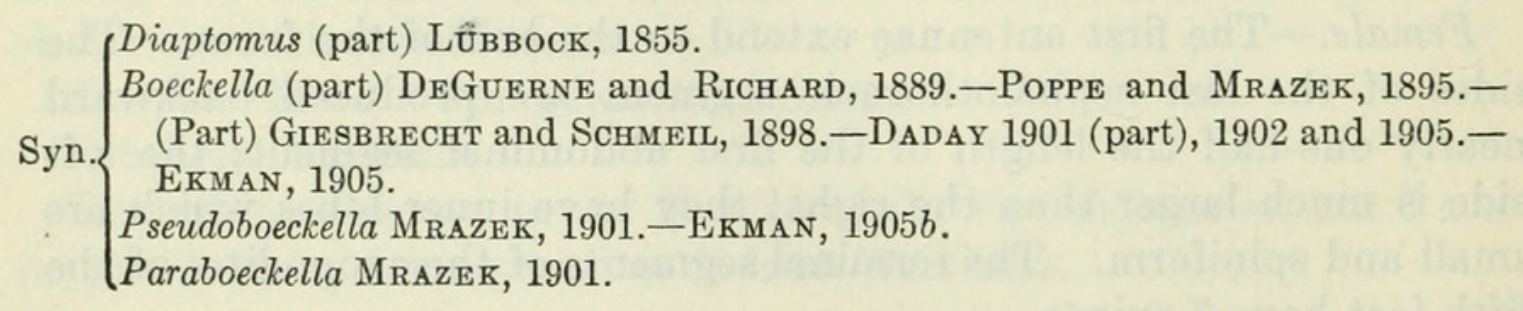


KEY TO SPECIES OF PSEUDOBOECKELLA MRAZEK.

The terminal segments of the exopodites of the fifth feet of the female have 3

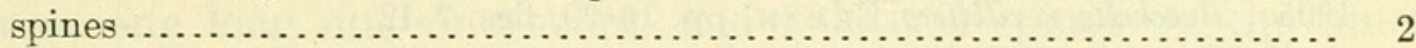

The terminal segments of the exopodites of the fifth feet of the female have 5 spines. silvestri Daday.

1. The terminal segments of the exopodites of the fifth feet of the female have 6

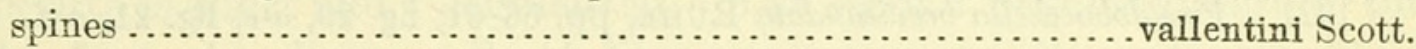

The terminal segments of the exopodites of the fifth feet of the female have 7

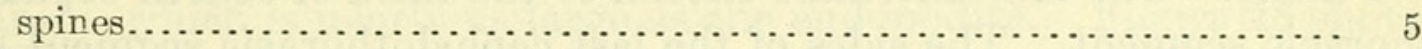

${ }_{2}$ The left endopodite of the male fifth feet consists of 1 segment. braziliensis Lubbock.

. The left endopodite of the male fifth feet consists of 2 segments.............. 3

(In the left fifth foot of the male the second segment of the exopodite has 2 spines

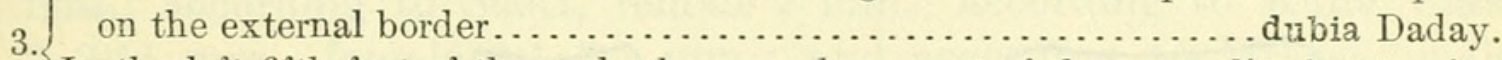

In the left fifth foot of the male the second segment of the exopodite has 1 spine on the external border ........................................... 4

The second segment of the left exopodite of the fifth feet of the male has a small

4. spine on the internal side at the base of the hook............. setosa Daday.

4. The second segment of the left exopodite of the fifth feet of the male does not have a small spine on the inner side at the base of the hook........ longicauda Daday.

In the 3-segmented endopodite of the right male fifth foot the second and third segments are slender, the third segment is terminated with 2 spines; the left endopodite is 2 segmented...................... brevicaudata Mrazek.

5. In the 3 -segmented endopodite of the right male fifth foot the second and third segments are not especially slender and the third is armed with 4 stout spines; the left endopodite is 2 segmented ..................... poppei Mrazek.

\section{PSEUDOBOECKELLA BRAZILIENSIS Lubbock.}

1854. Diaptomus braziliensis LubBock, pp. 236-240, pl. 15, figs. 3-8.

1889. Boeckella braziliensis DeGuerne and Richard, pp. 100-102, figs. 54-56 (from Lubbock).

1901. Psuedoboeckella braziliensis Mrazek, pp. 5-6, pl. 1, figs. 11 and 13; pl. 2, figs. 24 and 30.

1905b. Pseudoboeckella braziliensis Eкмan, p. 600.

Not Pseudoboeckella braziliensis Poppe and Mrazek, nor Daday.

Female.-The first antennae extend to the last cephalothoracic segment. The sides of the last cephalothoracic segment extend back nearly to the second abdominal segment; they do not have inner lobes and their inner margins are nearly straight. The terminal segments of the exopodites of the fifth feet have 3 spines.

Male.-In the fifth feet the hook in both exopodites bears a small spine on the inner side; in the right foot the spine is situated at about one-third the length of the hook and in the left at about one-half. In the right endopodite the three segments are approximately equal in length and the whole endopodite equals the first 2 segments of the exopodite. The left endopodite is short and composed of 1 segment. Figure 27 shows the fifth feet of the male.

Length.-Male, $1.6 \mathrm{~mm}$; female, $2 \mathrm{~mm}$.

Patagonia; Tierra del Fuego. 


\section{PSEUDOBOECKELLA BREVICAUDATA Mrazek.}

1901. Paraboeckella brevicaudata Mrazek, pp. 8-11, figs. 7, 12, 21, 26, and 27. 1905a. Boeckella vexillifera Eкмал, pp. 16-20, figs. 7-12.

1905b. Pseudoboeckella brevicaudata Eкмan, pp. 600-601.

1905b. Pseudoboeckella brevicaudata, var. vexillifera Eкмал, p. 601.

1914. Pseudoboeckella brevicaudata Sсотт, T., pp. 4-5, pl. 1, figs. 1, 7, and 10.

1921. Pseudoboeckella brevicaudata RüHE, pp. 56-61, fig. 20, a-e, fig. 21, a-d.

Female.-The first antennae extend to the third or fourth cephalothoracic segment. The sides of the last cephalothoracic segment are asymmetrical, the left side being the larger; there are no inner lobes, but the inner margins are sinuate; they extend backward according
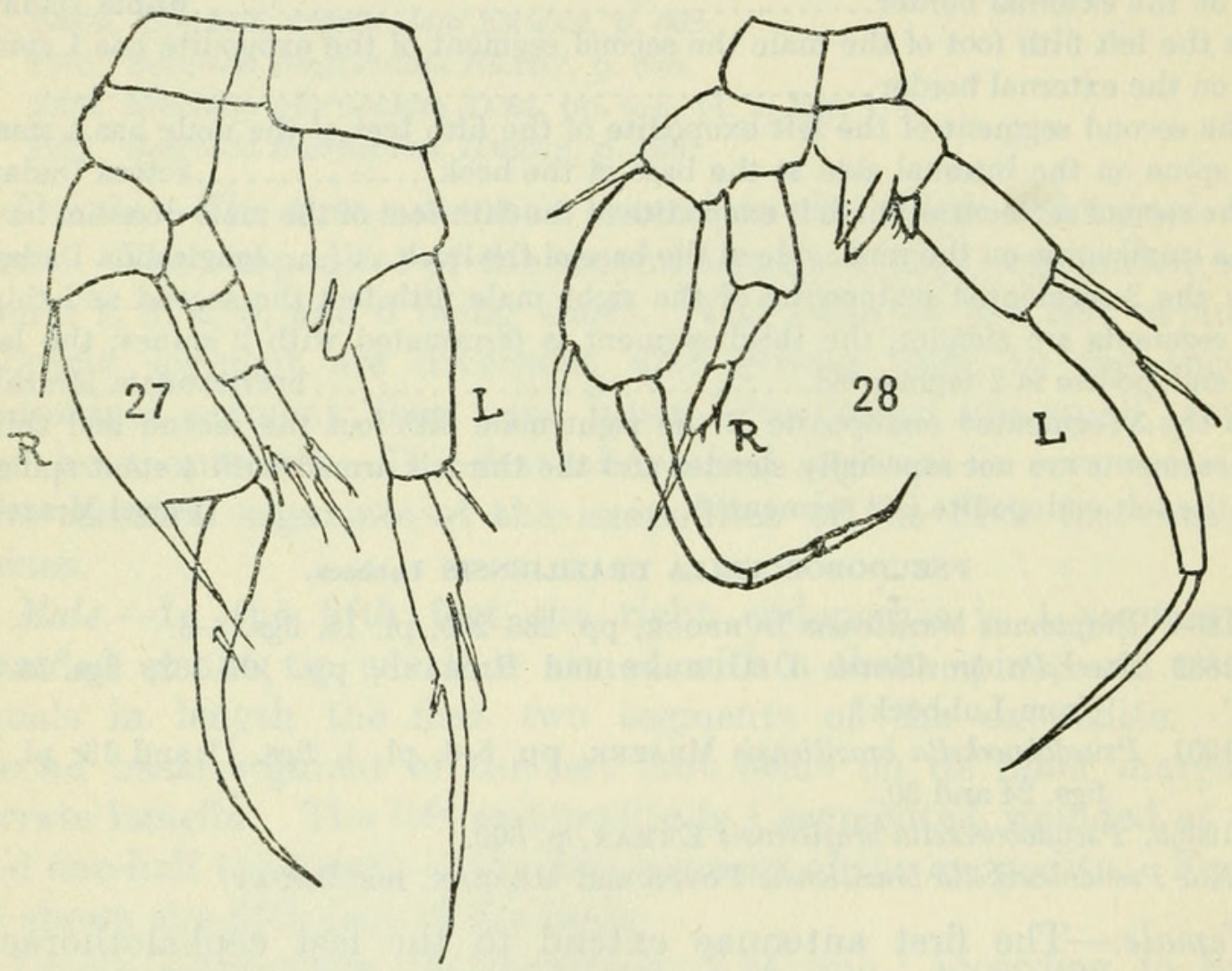

Figs. 27-28.-27, Pseudoboeckella braziliensis Lubbock, fifth feet of Male, after Mrazek. 28, P. brevicaudata MrazeK, Fifth feet of Male, after MrazeK.

to Ekman's figure one-half the length of the first abdominal segment, according to Rühe's figure beyond the first abdominal segment. The terminal segments of the exopodites of the fifth feet have 7 spines.

Male.- In the fifth feet the second segment of the right exopodite is slender, somewhat curved, and bears on its distal end a curved hook whose general position is approximately at right angles with the second segment. The right endopodite is 3 segmented, the first segment being nearly as broad as long, and the second and third segments long and slender; the third segment bears at the tip 2 spines, one long and one short; these 2 spines are shown in the figures of Ekman and Scott, but only 1 in the figures of Mrazek and Rühe; Mrazek, Ekman, and Rühe show also on this third segment 2 small lateral spines. Scott shows no lateral spines; if we may assume 
slight errors in some of the figures, it would seem probable that the armature of this segment, typically at least, consists of 2 terminal spines, one long and one short, and 2 lateral spines on the inner margin. The left exopodite is 2 segmented, the second segment bearing a lateral spine and a terminal scythe-shaped hook; the endopodite is short and 1 segmented. The second basal segment of the right foot also bears a hook-like projection on its anterior distal margin, which is nearly as large as the endopodite. Figure 28 shows the fifth feet of the male.

Length.-According to Ekman, male 2-2.55 mm., female 2.9-3 $\mathrm{mm}$.; according to Scott, female $2 \mathrm{~mm}$; according to Rühe, male 2-2.55 mm., female 2.1-3.1 mm.; and according to Mrazek, male $18 \mathrm{~mm}$., female $21 \mathrm{~mm}$. It seems probable that Mrazek's figures of size are a misprint and that they should be, male $1.8 \mathrm{~mm}$., female $2.1 \mathrm{~mm}$.

Patagonia; Tierra del Fuego; Falkland Islands; Kerguelen Island; New Amsterdam Island.

This has by some been considered identical with Centropages brevicaudatus Brady, 1875 and 1879, but Brady's description is so brief and incomplete that identification of his form is impossible.

\section{PSEUDOBOECKELla DUBIA Daday.}

1901. Boeckella dubia DADAY, p. 345.

1902. Boeckella dubia DADAY, pp. 236-239, pl. 6, figs. 1 and 2.

1905b. Boeckella dubia EкмаN, p. 600.

Female.-The first antennae extend to the last cephalothoracic segment. The sides of the last cephalothoracic segment extend back to the end of the first abdominal segment and are acute and slightly lobed on the inner margin. The terminal segments of the exopodites are armed with 3 spines.

Male.-In the fifth feet the right endopodite is 3 segmented and longer than the first 2 segments of the exopodite. There is a cuticular extension of the inner distal angle of the second basal segment of the left foot, covering about one-half the first segment of the endopodite. The second segment of the left exopodite bears 2 spines. The left endopodite is 2 segmented, the distal segment bearing at its outer end a spine; with the spine the endopodite equals in length the first segment of the exopodite. Figure 29 shows the fifth feet of the male.

Length.-Male, $2.6 \mathrm{~mm}$; female, $2.5-3 \mathrm{~mm}$.

Patagonia.

\section{PSEUDOBOECKELLA LONGICAUDA Daday.}

1901. Boeckella longicauda DADAY, pp. 346-347.

1902. Boeckella longicauda DADAY, pp. 243-247, pl. 6, figs. 10, 14, and 16 .

1905b. Pseudoboeckella longicauda Ekman, p. 600.

Female.-The first antennae extend to the last cephalothoracic segment. The sides of the last cephalothoracic segment extend 
backward one-half the length of the first abdominal segment; the ends are turned slightly outward and are acute; the inner margin is sinuate. The terminal segments of the exopodites bear 3 spines.

Male.-The right endopodite of the fifth feet is slender, 3 segmented, and equal in length to the first 2 segments of the exopodite. The second basal segment of the left foot bears on its inner distal angle a cuticular projection which is as long as the endopodite. The left endopodite is 2 segmented, somewhat less than one-half the length of the first segment of the exopodite, and its terminal segment is tipped with a small blunt spine. Figure 30 shows the fifth feet of the male.

Length.-Male, 2.6-2.8 mm.; female, 3.6-3.8 mm.

Patagonia.
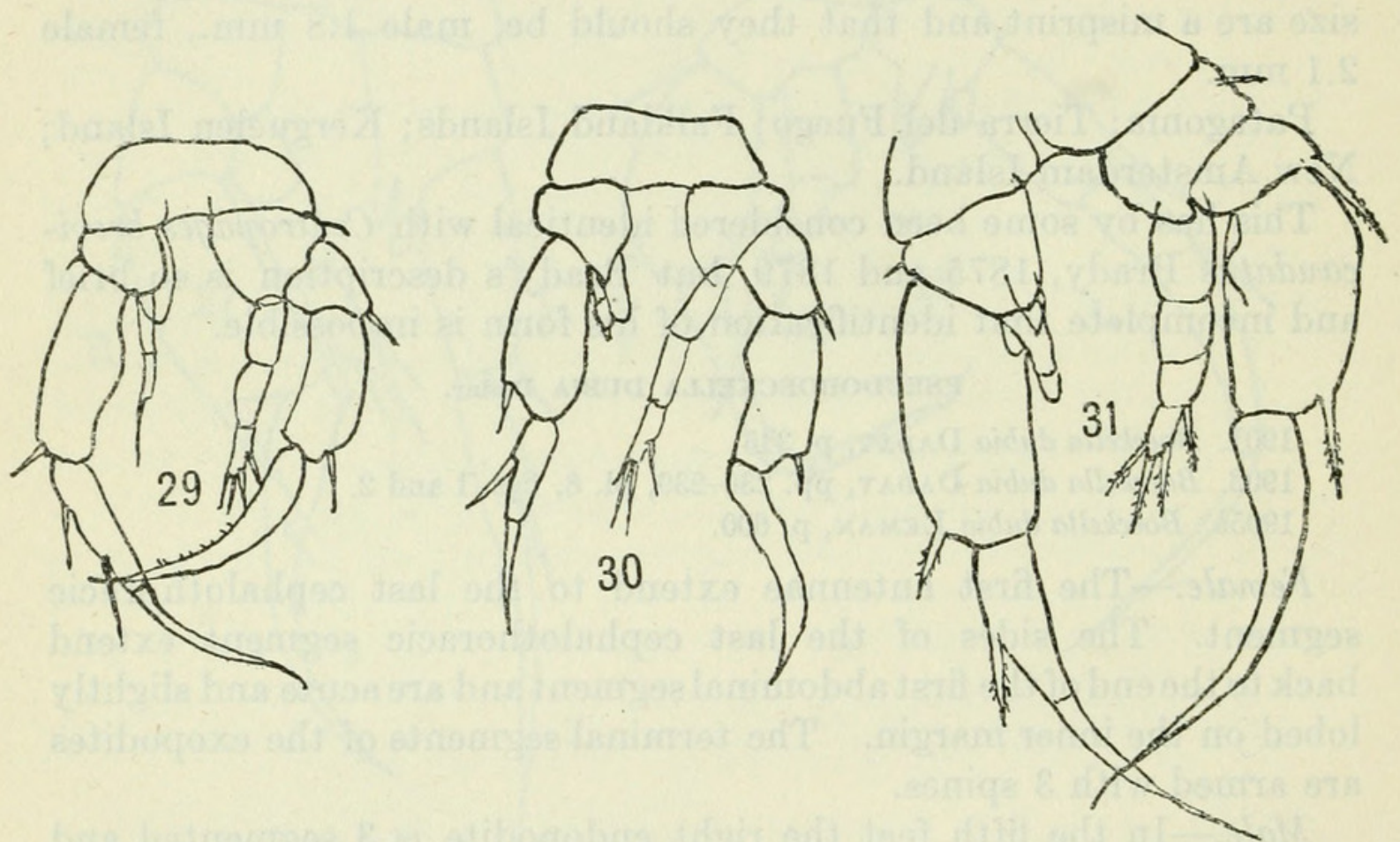

Figs. 29-31.-29, Pseudoboeckella dubia Daday, fifth feet of Male, after Daday. 30, P. LongiCaUda Daday, fifth feet of male, after Daday. 31, P. Poppei Mrazek, fifth feet of male, AFTER POPPE AND MRAZEK.

\section{PSEUDOBOECKELLA POPPEI Mrazek.}

1895. Boeckella braziliensis, Poppe and Mraze K, pp. 13-16, figs. 1-11.

1898. Boeckella braziliensis Giesbrecht and Schmeil (part), p. 60.

1901. Pseudoboeckella poppei Mrazeк, p. 6.

1901. Boeckella entzii DADAY, pp. 345-346.

1902. Boeckella entzii DadAY, pp. 239-243, pl. 6, figs. 3-9.

1905b. Pseudoboeckella poppei Ekman, p. 600.

1909. Pseudoboeckella poppei Sars, pp. 22-29, pl. 3, figs. 1-16.

Female.-The last segment of the cephalothorax projects back fully one-half the length of the first abdominal segment; the sides do not have inner lobes, but the inner margins are sinuate. The first abdominal segment is somewhat asymmetrical, projecting more to the left side. The terminal segments of the exopodites of the fifth feet have 7 spines. 
Male.-The lobes of the last cephalothoracic segment are much smaller than in the female. In the fifth feet the right endopodite consists of 3 segments and the terminal segment is armed with 4 spines. The left endopodite is 2 segmented and is very small. Figure 31 shows the fifth feet of the male.

Length.-As given by Daday for entzii, male, 2.2-3 mm.; female, 2.6-3.5 mm. The other authors do not give the size.

South Georgia; Patagonia.

\section{PSEUDOBOECKELLA SETOSA Daday.}

1901. Boeckella setosa DadAY, p. 347.

1902. Boeckella braziliensis DADAY, pp. 247-251, pl. 6, fig. 15; pl. 7, figs. 1-6.

Female.-The first antennae equal in length the cephalothorax. The sides of the last cephalothoracic segment are produced backward
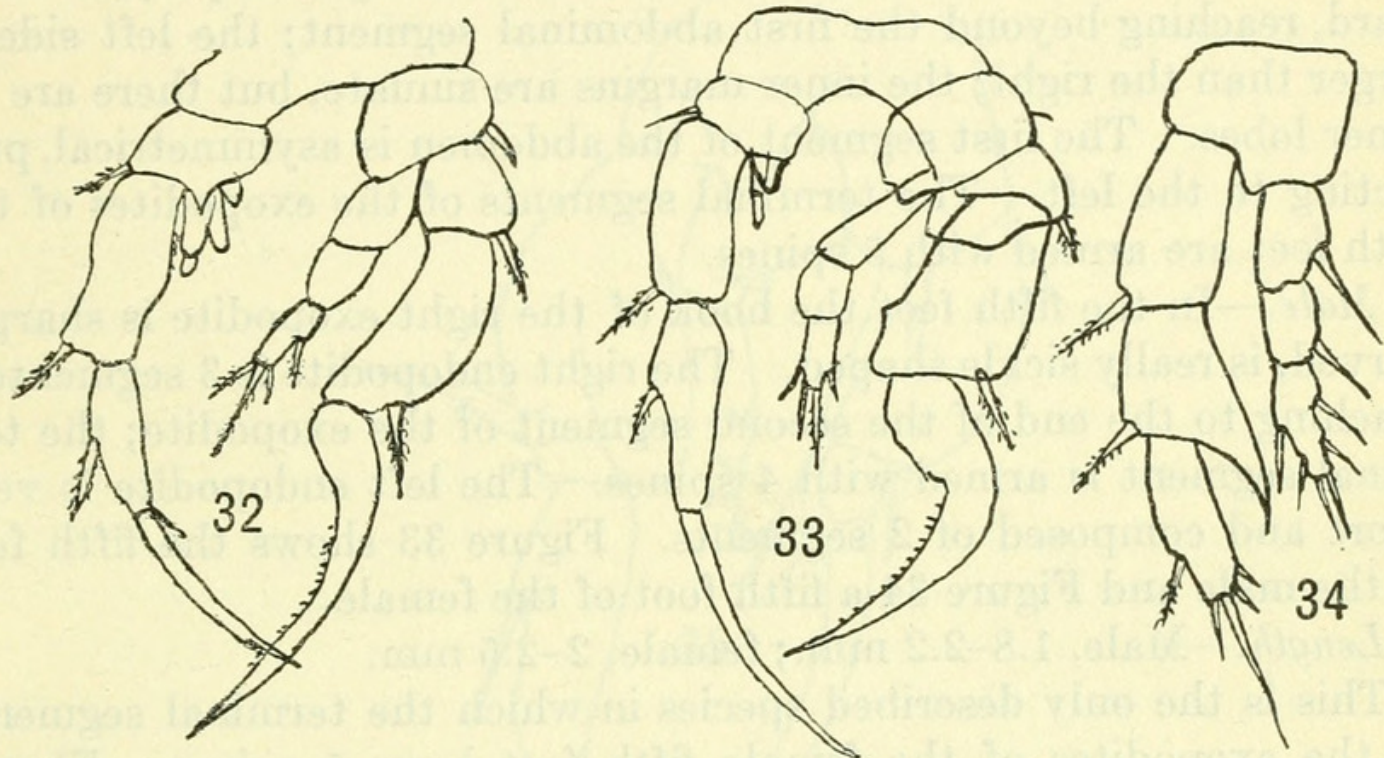

Figs. 32-34.-32, Pseudoboeckella setosa Daday, fifth feet of male, after Daday. 33, P. SilVESTRI DADAY, FIFTH FEet OF MALE, AFTER DADAY. 34, P. SILVESTRI DADAY FIFTH Foot OF FEMALE, AFTER DADAY.

nearly to the second abdominal segment; they do not have interior lobes, but are sinuate on the inner margins. The terminal segments of the exopodites of the fifth feet have 3 spines.

Male.-The endopodite of the right fifth foot equals in length the first 2 segments of the exopodite; the terminal segment is armed with 4 spines. The left endopodite of the fifth feet is 2 segmented and about one-half the length of the first segment of the exopodite. The second segment of the left exopodite has 1 spine on the external border and also a small spine on the internal side at the base of the hook. Figure 32 shows the fifth feet of the male.

Length.-Male, 1.6-2 mm.; female, 1.8-2.2 $\mathrm{mm}$.

Patagonia.

Daday, 1902, makes B. setosa a synonym of B. braziliensis Daday and $D$. braziliensis Lubbock. It seems probable that setosa Daday 
and braziliensis Daday are the same. B. braziliensis Daday, however, is not $D$. braziliensis Lubbock, for the endopodite of the left fifth foot of the male in Lubbock's species is 1 segmented, but in Daday's 2 segmented. Moreover Mrazek's figure shows a small spine on the inner side of the hook of the exopodite of the male fifth foot, and this does not appear in Daday's figure. It seems best, therefore, to use setosa as the name of the species.

\section{PSEUDOBOECKELLA SILVESTRI Daday.}

1901. Boeckella silvestri DADAY, p. 348.

1902. Boeckella silvestri DADAY, pp. 251-255, pl. 7, figs. 7-15.

1905a. Boeckella entzii Eкмan, pp. 15-16, pl. 1, fig. 6.

1905b. Pseudoboeckella entzii Eкмan, p. 600.

Female.-The first antennae reach the end of the first abdominal segment. The sides of the last cephalothoracic segment project backward, reaching beyond the first abdominal segment; the left side is larger than the right; the inner margins are sinuate, but there are no inner lobes. The first segment of the abdomen is asymmetrical, projecting to the left. The terminal segments of the exopodites of the fifth feet are armed with 5 spines.

Male.-In the fifth feet the hook of the right exopodite is sharply curved, is really sickle shaped. The right endopodite is 3 segmented, reaching to the end of the second segment of the exopodite; the terminal segment is armed with 4 spines. The left endopodite is very short and composed of 2 segments. Figure 33 shows the fifth feet of the male and Figure 34 a fifth foot of the female.

Length.-Male, 1.8-2.2 mm.; female, 2-2.5 mm.

This is the only described species in which the terminal segments of the exopodites of the female fifth feet have 5 spines. Ekman gives no description of $B$. entzii and has only one figure; that figure, however, is of the female fifth foot and shows the terminal segment of the exopodite with five spines. In lack of further description it would seem that it should be considered identical with Daday's silvestri.

Daday reported silvestri from Patagonia. Ekman reported his entzii from Louis Philippe Land, Southern Georgia, and the Falkland Islands. If the preceding identifications are correct, it must have a fairly wide distribution.

\section{PSEUDOBOECKELLA VALLENTINI T. Scott.}

1914. Pseudoboeckella vallentini T. Scotт, pp. 5-7, pl. 1, figs. 2, 8, and 11.

Female.-The first antennae reach the third segment of the abdomen. The sides of the last cephalothoracic segment are straight, that is flare outward very little, rounded at the tips, and have inner lobes. The hook of the second segment of the exopodites of the fifth feet is long, extending beyond the end of the third segment, and is 
slightly recurved at the tip. The terminal segments of the exopodites have 6 spines.

Male.-In the fifth feet the second basal segment of the right foot in addition to the spine at the outer distal angle has a 2-pointed spine at the inner distal angle. The right endopodite is 1 segmented, exceeds the first segment of the exopodite in length, has 2 stout curved spines at the inner distal angle and upon the tip and extending along the inner side 5 shorter stout curved spines. There is also a straight acute spine near the proximal end on the inner margin. The left endopodite in Scott's figure does not seem to be separated from the second basal segment; it is 1 segmented or perhaps rudimentary. Figure 35 shows the fifth feet of the male.

Length.-Female, $1.6 \mathrm{~mm}$.

Falkland Islands.

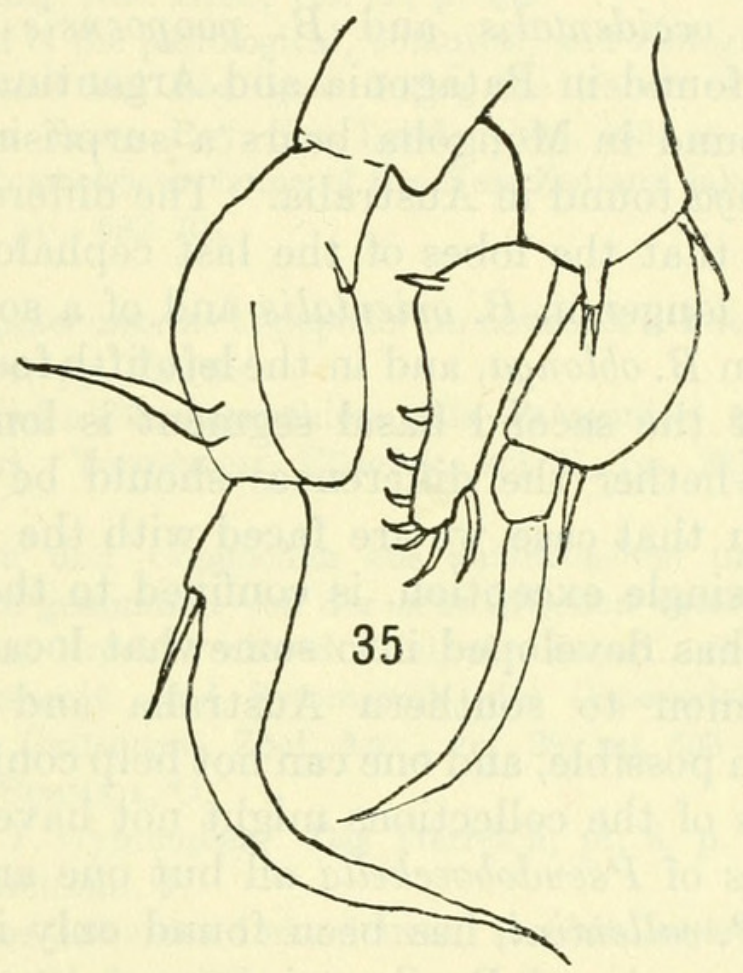

Fig. 35.-Pseudoboeckella vallentini Scott, fifth feet of Male, after Scott.

\section{DISTRIBUTION OF THE SPECIES OF BOECKELLA AND PSEUDOBOECKELLA.}

The distribution of the fresh-water Centropagidae is a matter of a good deal of interest, as they are much more restricted in their habitats than some other forms of the Copepoda; for example, many of the species of the Cyclopidae are world-wide in their distribution while many of the species of the Centropagidae are found only over somewhat limited areas. The morphological differences, due to environment, make it possible in the case of the species of the Centropagidae to make some conjectures in regard to their phylogeny.

Both Boeckella and Pseudoboeckella are genera of the southern continents. Only one species, $B$. orientalis, is found north of the 
equator, and, as stated later, the author is inclined to think that there must be some mistake about this species.

The genus Boeckella occurs in Australia, Tasmania, New Zealand, in South America from Tierra del Fuego to Lake Titicaca, and in the Falkland Islands. There are 8 species in Australia, 3 in Tasmania, 2 in New Zealand, 6 in South America, 1 in the Falklands, and 1 in Mongolia. One species, B. triarticulata, has been found in both Australia and New Zealand. With this exception, of Australia, New Zealand and Tasmania, each has its peculiar species. The South American species are all distinct from those of Australia, New Zealand, and Tasmania. One South American species, B. michaelseni, has been found in the Falkland Islands. With this exception none of the South American species has been found away from the continent. $B$. gracilipes and $B$. occidentalis have been found in Lake Titicaca and $B$. occidentalis and $B$. poopoensis in Lake Poopo. The others were found in Patagonia and Argentina.

$B$. orientalis found in Mongolia bears a surprisingly close resemblance to B. oblonga found in Australia. The differences as shown in Sars's figures are that the lobes of the last cephalothoracic segment of the female are longer in $B$. orientalis and of a somewhat different form from those in B. oblonga, and in the left fifth foot of the male the serrate lamella of the second basal segment is longer. It may be a fair question whether the differences should be considered more than varietal. In that case we are faced with the fact that a genus which, with this single exception, is confined to the southern continents, and there has developed into somewhat localized species, has one species common to southern Australia and Mongolia. This would hardly seem possible, and one can not help conjecturing whether the locality labels of the collections might not have been misplaced.

Of the 8 species of Pseudoboeckella all but one are found in Patagonia; this one, P.vallentini, has been found only in the Falklands. Two species, $P$. poppei and $P$. silvestri, occur not only in Patagonia but in South Georgia, and P. silvestri has been found also in Louis Philippe Land and the Falkland Islands. P. brevicaudata has a rather surprising distribution, for besides occurring in Patagonia and Tierra del Fuego it has been collected in Kerguelen and New Amsterdam Island. It certainly is strange that this species should be found in the islands in the Indian Ocean but not on any of the islands near South America. Of course, in any discussion of the distribution of these forms, it should be remembered we are speaking only of the localities in which the species have been found, and that the islands bordering the Antarctic have been very imperfectly explored for their invertebrate fauna.

In regard to the manner in which these species were distributed, it should be said that while there is no impossibility, theoretically, 
of birds carrying them in mud attached to their feet, there is little evidence that this actually occurs, while observed facts seem to indicate that the ordinary means of distribution of fresh-water copepods is by water transportation. It seems most probable, therefore, that the genera traveled from the Antarctic Continent, and the species have become differentiated in the various localities.

It may be noted that inasmuch as in the development of the Centropagidae there is a tendency to reduction of the endopodites of the fifth feet of the male, from a phylogenetic standpoint Pseudoboeckella would be considered more primitive than Boeckella.

\section{LITERATURE ON BOECKELLA AND PSEUDOBOECKELLA.}

BRADY, G. S.

1875. Note on Entomostraca from Kerguelen's Land and the South Indian

Ocean. Ann. Mag. Nat. Hist., vol. 16, p. 152.

1879. An account of the petrological, botanical, and zoological collections made in Kerguelen Land and Rodriguez during the transit of Venus expeditions, 1874-75. Philos. Trans. Roy. Soc. London, vol. 168, pp. 215-218.

1906. On the entomostracan fauna of the New Zealand lakes. Proc. Zool. Soc. London, 1906, pp. 692-701.

DADAY, E.

1901. Diagnoses praecursoriae Copepodorum novorum e Patagonia. Természetr.

Füzetek, vol. 24, pp. 345-350.

1902. Mikroskopische Süsswasserthiere aus Patogonien gesammelt von Dr.

Filippo Silvestri. Természetr. Füzetek, vol 25, pp. 201-310.

Ekman, Sven.

1905a. Cladoceren und Copepoden aus antarktischen und subantarktischen

Binnengewässern gesammelt von der schwedischen antarktischen Expedition

1901-1903. Wiss. Ergebn. schwed. Südpolar-Exped., vol 5, pt. 4, pp. 1-40.

1905b. Die Systematik und Synonymik der Copepodengattung Boeckella

und verwandter Gattungen, Zool. Anz., vol. 29, pp. 593-604.

Giesbrecht, W., and Schmeil, O.

1898. Copepoda. I. Gymnoplea. Das Tierreich, pt. 6, p. 169.

DeGuerne, J., and Richard, J.

1889. Révision des Calanides d'eau douce. Extrait des mémoires de la Société

Zool. de France, vol. 2, p. 129.

Henry, Marguerite.

1919. On some Australian freshwater Copepoda and Ostracoda. Journ. and Proc. Roy. Soc. of New South Wales, vol. 53, pp. 29-48.

1922. A monograph of the freshwater Entomostraca of New South Wales. Part

2, Copepoda. Proc. Linn. Soc. New South Wales, vol. 47, pt. 4, 1922, pp. $551-570$.

LUввоск, J.

1854. On the fresh water Entomostraca of South America. Trans. Entomol.

Soc. London, new ser., vol. 3, pp. 232-240.

Marsh, C. Dwight.

1906. Les lacs des hauts plateaux de l'Amerique du Sud, par Dr. M. Neveu -

Lemaire, Soudier, Paris. Copépodes par C. Dwight Marsh, pp. 175-188.

MrazeK, Al.

1901. Süsswasser-Copepoden. Ergebn. Hamburg Magalhaens, Sammelr., pt. 6, No. 2, 29 pp. 
Poppe, S. A., and Mrazek, A.

1895. Entomostraken des Naturhist. Mus. in Hamburg, 2, Entomostraken von Süd-Georgien. pp. 13-16.

RichaRd, Jules.

1897. Sur quelque entomostracés d'eau douce des environs de Buenos Aires.

Anales del Museo Nacional de Buenos Aires, vol. 5, pp. 321-332.

SARS, G. O.

1894. Contributions to the knowledge of the fresh water Entomostraca of New Zealand, as shown by artificial hatching from dried mud. Vid. Selsk. Skifter, No. 5 , p. 49.

1896. On fresh-water entomostraca from the neighborhood of Sydney, partly raised from dried mud. Arch. Math. Naturv. Kristiania, vol 18, No. 3, 81 pp.

1897. Pelagic entomostraca of the Caspian Sea. Ann. Mus. Zool. Acad. Imp. Sci. St. Pétersbourg, vol. 2, pp. 1-73.

1903. On the crustacean fauna of Central Asia. Ann. Mus. Zool. Acad. Sci. St. Pétersbourg, vol. 8, No. 2, pt. 3, Copepoda and Ostracoda, pp. 195-232.

1904. Pacifische Plankton-Crustaceen. Zool. Jahrb. Syst. Geog. and Biol., vol. 19, pp. 629-646.

1908. Fresh water copepoda from Victoria, southern Australia. Arch. Math. Naturv. Kristiania, vol. 29, No. 7, pp. 1-24.

1909. Fresh water entomostraca from South Georgia. Arch. Math. Naturv. Kristiania, vol. 30, p. 29.

1912. Additional notes on fresh-water Calanoida from Victoria, southern Australia. Arch. Math. Naturv. Kristiania, vol. 32, No. 13, 20 pp.

Scotт, Thomas.

1914. Remarks on some Copepoda from the Falkland Islands collected by Mr. Rupert Vallentin. Ann. Mag. Nat. Hist., ser. 8, vol. 13, pp. 1-11.

SeARle, J.

1912. Some new Victorian Copepoda. Victorian Natural., vol. 28, pp. 196-198.

1914. An addition to the Victorian fresh water Copepoda. Victorian Natural., vol. 30, pp. 191-192.

Simth, Geoffrey Watkin.

1909. The fresh water Crustacea of Tasmania with remarks on their geographical distribution. Trans. Linn. Soc. London, Zool., ser. 2, vol. 11, pp. 61-92.

Tномson, G. M.

1883. On the New Zealand Copepoda. Trans. and Proc. New Zealand Institute, vol. 15, pp. 93-116. 


\section{$2 \mathrm{BHL}$ Biodiversity Heritage Library}

Marsh, C. Dwight. 1924. "A synopsis of the species of Boeckella and Pseudoboeckella with a key to the genera of the fresh-water Centropagidae." Proceedings of the United States National Museum 64(2498), 1-28. https://doi.org/10.5479/si.00963801.64-2498.1.

View This Item Online: https://www.biodiversitylibrary.org/item/32410

DOI: https://doi.org/10.5479/si.00963801.64-2498.1

Permalink: https://www.biodiversitylibrary.org/partpdf/1896

\section{Holding Institution}

Smithsonian Libraries

\section{Sponsored by}

Smithsonian

\section{Copyright \& Reuse}

Copyright Status: NOT_IN_COPYRIGHT

Rights: https://www.biodiversitylibrary.org/permissions/

This document was created from content at the Biodiversity Heritage Library, the world's largest open access digital library for biodiversity literature and archives. Visit BHL at https://www.biodiversitylibrary.org. 